\title{
Attribution and evolution of ozone from Asian wild fires using satellite and aircraft measurements during the ARCTAS campaign
}

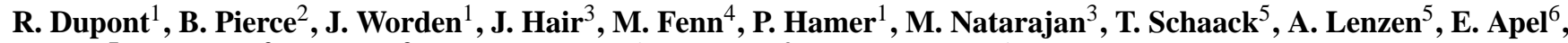

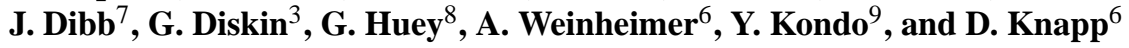 \\ ${ }^{1}$ Jet Propulsion Laboratory, California Institute of Technology, Pasadena, CA, USA \\ ${ }^{2}$ NOAA/NESDIS/STAR, Madison, WI, USA \\ ${ }^{3}$ NASA Langley Research Center, Hampton, VA, USA \\ ${ }^{4}$ Science Systems and Applications, Inc., Hampton, VA, USA \\ ${ }^{5}$ Space Science and Engineering Center, University of Wisconsin, Madison, WI, USA \\ ${ }^{6}$ National Center for Atmospheric Research, Boulder, CO, USA \\ ${ }^{7}$ University of New Hampshire - EOS, Durham, NH, USA \\ ${ }^{8}$ School of Earth and Atmospheric Sciences, Georgia Institute of Technology, Atlanta, GA, USA \\ ${ }^{9}$ Research Center for Advanced Science and Technology, University of Tokyo, Tokyo, Japan \\ Correspondence to: R. Dupont (richard.dupont@ @ive.fr)
}

Received: 22 September 2010 - Published in Atmos. Chem. Phys. Discuss.: 8 November 2010

Revised: 27 October 2011 - Accepted: 9 December 2011 - Published: 3 January 2012

\begin{abstract}
We use ozone and carbon monoxide measurements from the Tropospheric Emission Spectrometer (TES), model estimates of Ozone, $\mathrm{CO}$, and ozone pre-cursors from the Real-time Air Quality Modeling System (RAQMS), and data from the NASA DC8 aircraft to characterize the source and dynamical evolution of ozone and $\mathrm{CO}$ in Asian wildfire plumes during the spring ARCTAS campaign 2008. On the 19 April, NASA DC8 $\mathrm{O}_{3}$ and aerosol Differential Absorption Lidar (DIAL) observed two biomass burning plumes originating from North-Western Asia (Kazakhstan) and SouthEastern Asia (Thailand) that advected eastward over the Pacific reaching North America in 10 to 12 days. Using both TES observations and RAQMS chemical analyses, we track the wildfire plumes from their source to the ARCTAS DC8 platform. In addition to photochemical production due to ozone pre-cursors, we find that exchange between the stratosphere and the troposphere is a major factor influencing $\mathrm{O}_{3}$ concentrations for both plumes. For example, the Kazakhstan and Siberian plumes at 55 degrees North is a region of significant springtime stratospheric/tropospheric exchange. Stratospheric air influences the Thailand plume after it is lofted to high altitudes via the Himalayas. Using comparisons of the model to the aircraft and satellite measurements, we estimate that the Kazakhstan plume is responsible for increases of $\mathrm{O}_{3}$ and $\mathrm{CO}$ mixing ratios by approximately $6.4 \mathrm{ppbv}$ and $38 \mathrm{ppbv}$ in the lower troposphere (height of 2
\end{abstract}

to $6 \mathrm{~km}$ ), and the Thailand plume is responsible for increases of $\mathrm{O}_{3}$ and $\mathrm{CO}$ mixing ratios of approximately $11 \mathrm{ppbv}$ and $71 \mathrm{ppbv}$ in the upper troposphere (height of 8 to $12 \mathrm{~km}$ ) respectively. However, there are significant sources of uncertainty in these estimates that point to the need for future improvements in both model and satellite observations. For example, it is challenging to characterize the fraction of air parcels from the stratosphere versus those from the fire because of the low sensitivity of the TES CO estimates used to mark stratospheric air versus air parcels affected by the smoke plume. Model transport uncertainties, such as too much dispersion, results in a broad plume structure from the Kazakhstan fires that is approximately $2 \mathrm{~km}$ lower than the plume observed by aircraft. Consequently, the model and TES data do not capture the photochemical production of ozone in the Kazakhstan plume that is apparent in the aircraft in situ data. However, ozone and CO distributions from TES and RAQMS model estimates of the Thailand plume are within the uncertainties of the TES data. Therefore, the RAQMS model is better able to characterize the emissions from this fire, the mixing of ozone from the stratosphere to the plume, and the photochemical production and transport of ozone and ozone pre-cursors as the plume moves across the Pacific. 


\section{Introduction}

Wildfire emissions affect atmospheric composition on global scales (Andreae, 1983; Reichle et al., 1986; Fishman et al., 1990; Soja et al., 2007) with levels of carbon monoxide (CO), carbon dioxide $\left(\mathrm{CO}_{2}\right)$ and nitrogen oxides $\left(\mathrm{NO}_{\mathrm{x}}\right)$ comparable to fossil fuel emissions (Seiler and Crutzen, 1980; Crutzen and Andreae, 1990). During the last decade, measurement from satellites, aircraft, and ground-based observations have confirmed significant concentrations of $\mathrm{CO}, \mathrm{O}_{3}$ and other trace gases in regions affected by biomass burning (Thompson et al., 1992). Van der Werf et al. (2006) showed that global emissions of $\mathrm{CO}$ from biomass burning were $15 \%$ larger than fossil fuel emissions $\left(750 \mathrm{Tg}^{-1}\right)$. Similarly, global biomass burning emissions of $\mathrm{N}_{2} \mathrm{O}, \mathrm{CO}_{2}, \mathrm{NO}_{\mathrm{x}}$ were approximately $70 \%\left(1.4 \mathrm{Tg}^{-1}\right), 60 \%\left(14300 \mathrm{Tg}^{-1}\right)$ and $50 \%\left(22.5 \mathrm{Tg} \mathrm{y}^{-1}\right)$ of amounts from global fossil fuel emissions.

Satellite data have been used to monitor the extent and emissions of seasonal fires over Siberia/northeast Asia (Cahoon et al., 1994; Tanimoto et al., 2000; Kajii et al., 2002; Kato et al., 2002; Soja et al., 2004) and over the Southeast Asian subcontinent (Christopher et al., 1998; Goloub and Arino, 2000). Asian fires can represent $10 \%$ of global Carbon emissions (Van der Werf et al., 2006). Those fires play an important role in total tropospheric $\mathrm{CO}$ concentrations and interannual variability in the Northern Hemisphere (Novelli et al., 2003; Edwards et al., 2004; Kasischke et al., 2005; Pfister et al., 2005; Nedelec et al., 2005; Fisher et al., 2010).

Aircraft and ground-based measurements have shown that Asian fires can influence $\mathrm{O}_{3}$ concentrations over North America (Jaffe et al., 2004; Morris et al., 2006), the Arctic (Warnecke et al., 2008) and even Europe (Simmonds et al., 2005). For example, Bertschi and Jaffe (2005) have shown that Siberian fires have caused three ozone pollution events over the coast of Washington state in 2002. However, the impact of fires on tropospheric $\mathrm{O}_{3}$ concentrations is challenging to estimate. Indeed, $\mathrm{O}_{3}$ production is highly variable inside boreal fire plumes because of the influence of clouds and aerosols on photochemical production as well as highly variable PAN and $\mathrm{NO}_{\mathrm{x}}$ concentrations and the cycling between these species (Mauzerall et al., 1996; Lapina et al., 2006; Val Martin et al., 2006; Real et al., 2007; Verma et al., 2009).

During spring 2008, fires burned throughout Asia and Siberia. Smoke from these fires was observed across the Pacific by satellite and aircraft measurements during the ARCTAS/ARCPAC campaign. In this paper we use fire counts from the MODIS satellite instrument, $\mathrm{CO}$ and $\mathrm{O}_{3}$ profiles from Tropospheric Emission Spectrometer (TES), insitu measurements from ARCTAS aircraft data and the Realtime Air Quality Modeling System (RAQMS) to characterize the factors influencing $\mathrm{O}_{3}$ production and transport from these Asian fires.

\section{Overview of ARCTAS campaign}

\subsection{Spring ARCTAS 2008}

The NASA ARCTAS field campaign consisted of two phases; a spring and summer deployment and was part of the international IPY/POLARCAT arctic field program for atmospheric composition (http://www.polarcat.no/), which involved a consortium of countries several aircraft, surface, and shipbased measurement platforms.

The Spring phase of the ARCTAS campaign took place as a 3-week aircraft deployment in April 2008. It involved the NASA DC8 as an airborne platform for detailed atmospheric composition and two smaller aircraft to focus more closely on aerosols and radiation. As a complement to aircraft measurements, NASA's polarorbiting satellites (e.g. Terra, Aura, and the Atrain) observe the longrange transport of pollution and its seasonal accumulation in the Arctic, enabling a better understanding of pollution sources, transport pathways, and radiative impacts of boreal smoke plumes.

ARCTAS has four major scientific themes, including the impact of Boreal forest fires on atmospheric composition, and long-range transport of pollution to the Arctic including tropospheric ozone. As an atmospheric receptor of longrange transport of pollutants from the northern midlatitudes continents (Shaw, 1995; Quinn et al., 2007), the Arctic is increasingly beset by emissions from massive forest fires in boreal Eurasia (Hao and Ward, 1993; Cahoon et al., 1994; Tanimoto at al., 2000; Fromm et al., 2000; Dlugokenchy et al., 2001; Conard et al., 2002; Kasischke and Bruhwiler, 2003). However, there remain large uncertainties regarding the transport pathways and the relative contributions of different source regions to Arctic pollution (Staudt et al., 2001; Heald et al., 2003a; Liu et al., 2003; Liang et al., 2004; Koch and Hansen, 2005; Stohl, 2006; Shindell et al., 2008; Turquety et al., 2008; Shindell et al., 2008; Yashiro et al., 2009; Fisher et al., 2010; Jacob et al., 2010). Integration of satellite and aircraft observations with models through ARCTAS provides a means to address this issue (Eckhardt et al., 2003; Klonecki et al., 2003; Koch and Hansen, 2005; Stohl, 2006; Shindell et al., 2008). Spacebased observations of CO and ozone from the Tropospheric Emission Spectrometer (TES) are of particular interest for characterizing synoptic transport events, the seasonal buildup of pollution during winter and spring and ventilation of the Arctic to midlatitudes in spring and summer.

Another major focus of ARCTAS is to evaluate chemical transport model (CTM) simulations of sourcereceptor relationships for pollutants in the Arctic which is a challenge because of the complexity of the transport patterns involved, the paucity of meteorological data, the stratification of the atmosphere, and uncertain chemistry and surface interactions. 


\subsection{Overview of TES}

TES is an infrared Fourier transform spectrometer that measures the thermal emission of the Earth's surface and atmosphere over the spectral range $650-2250 \mathrm{~cm}^{-1}$. It was designed to provide simultaneous vertical profile retrievals of tropospheric $\mathrm{O}_{3}, \mathrm{CO}$ and other trace gases on a global basis (Beer et al., 2001; Beer, 2006). The nadir footprint is $5.3 \mathrm{~km}$ across the spacecraft ground track and $8.5 \mathrm{~km}$ along track for the 16-detector average (Beer et al., 2001). TES has two basic science operating modes: Global Survey and Special Observations. Global Surveys are conducted every other day while special observations are taken as needed in between Global Surveys. We used global survey observations of TES $\mathrm{O}_{3}$ and $\mathrm{CO}$ obtained between 7 April and 19 April 2008 with a nadir sampling of 1.6 degrees spacing along the ground track.

The analysis presented here utilizes TES version 003 data (Osterman, 2007). An overview of the TES retrieval algorithm and error estimation are discussed by Bowman et al. (2006) and the characterization of errors and vertical information for individual TES profiles are discussed by Worden et al. (2004) and Kulawik et al. (2006). The vertical resolution of TES nadir $\mathrm{O}_{3}$ retrievals is about $6 \mathrm{~km}$ for cloud-free scenes, with sensitivity to both the lower and upper troposphere (Worden et al., 2004; Bowman et al., 2006). To date, TES tropospheric $\mathrm{O}_{3}$ validation has been conducted through comparisons with ozonesondes (Worden et al., 2007) and lidar (Richards et al., 2008). These validation studies show that TES $\mathrm{O}_{3}$ estimates are typically biased high in the upper troposphere by approximately $10 \%$. Nassar et al. (2008) shows that TES $\mathrm{O}_{3}$ is biased high by $3-10 \mathrm{ppb}$ in the upper troposphere. For the springtime ARCTAS measurements, TES CO estimates typically have 1 degree of freedom for signal, when averaged over the free troposphere, and have uncertainties of 10-20\% (e.g. Worden et al., 2004; Zhang et al., 2006). TES CO retrieval accuracy have been assessed through comparisons to aircraft in-situ measurements during INTEX-B (International Chemical Transport Experiment) 2006, AVE (Aura Validation Experiment, Houston, TX) 2004, CR-AVE (San Jose, Costa Rica) 2006, and PAVE (Polar Aura Validation Experiment) 2006 (Luo et al., 2007). The agreement between TES CO profiles and in situ data is typically within $15 \%$ and Lopez et al. (2008) reported that, in the $700-200 \mathrm{hPa}$ pressure range where TES is the most sensitive to $\mathrm{CO}$, in-situ measurements from the WB-57 aircraft agree with TES to within 5-10\%. Global comparisons between MOPITT (Measurement of Pollution in The Troposphere) and TES CO measurements have been performed as well (Ho et al., 2009) and show that for pressure layers where both instruments are most sensitive, the retrievals agree to within $10 \%$. In the same way, comparison between TES CO data in the upper troposphere and those from the ACE instrument show an agreement of $7.4 \%$ at $316 \mathrm{hPa}$.

\subsection{Real-time air quality modeling system: overview}

Chemical and aerosol analyses from the Real-Time Air Quality modeling System (RAQMS) and ensemble wild fire trajectories are used to examine the different processes influencing the evolution of trace gases (e.g. $\mathrm{O}_{3}$ and $\mathrm{CO}$ ) within fire plumes prior to sampling these plumes by the DC8. RAQMS is a unified (stratosphere/troposphere), online (meteorological, chemical, and aerosol) modeling system which has been developed for assimilating satellite observations of atmospheric chemical composition and providing real-time predictions of trace gas and aerosol distributions (Pierce et al., 2003, 2007; Kittaka et al., 2004). The chemical formulation follows a family approach with partitioning on the basis of photochemical equilibrium approximations. The non-methane hydrocarbon (NMHC) chemical scheme is based on the carbon bond lumped structure approach (Pierce et al., 2007). Photolytic rates are calculated using the FAST-JX code, an updated version of FASTJ2 code (Bian et al., 2003). The RAQMS aerosol model incorporates online aerosol modules from GOCART (Chin et al., 2002, 2003). Seven aerosol species $\left(\mathrm{SO}_{4}\right.$, hydrophobic and hydrophilic organic carbon (OC), and black carbon (BC), dust, sea-salt) are transported. Biomass burning emissions in the RAQMS model includes daily, ecosystem and severity based estimates based on Moderate Resolution Imaging Spectroradiometer (MODIS) Terra and Aqua fire detections (Al-Saadi et al., 2008). Fire emissions are a function of the fire severity and are injected over the depth of the planetary boundary layer for all fires except severe boreal fires, in which case the fire emissions are injected to $1 \mathrm{~km}$ above the planetary boundary layer. Fire severity is estimated using the Haines index (Haines, 1988) developed by the US Forest Service. Emissions of other species are determined by combining published emission ratios for different ecosystems (Cofer et al., 1991; Andreae and Merlet, 2001).

The RAQMS chemical analysis used in the current study is from a retrospective 4-month (February-May 2008) $2 \times 2^{\circ}$ assimilation that includes assimilation of cloud cleared OMI total column $\mathrm{O}_{3}$ measurements and stratospheric $\mathrm{O}_{3}$ profiles from the Microwave Limb Sounder (MLS) on the NASA Aura satellite. MODIS Aerosol Optical Depth (AOD) from instruments onboard the Terra and Aqua satellites (Remer et al., 2005; Davies et al., 2004) was also assimilated. A Mie code based look-up table of speciated aerosol mass extinction coefficients and relative humidity dependent hygroscopic growth factors is used to convert the predicted aerosol mass to speciated extinction, which is integrated vertically to obtain a first guess AOD for assimilation. The masses of all aerosol species are adjusted within each model layer on the basis of the total AOD analysis increment and the relative contribution of each aerosol species to the total layer extinction. The resulting RAQMS aerosol analysis is in good agreement with April 2008 global Aeronet measurements $(r=0.7$, bias $=0.05)$. During the chemical and aerosol 
assimilation cycle the RAQMS meteorological forecasts are reinitialized from NOAA Global Forecasting System (GFS) analyses at $6 \mathrm{~h}$ intervals.

We have also conducted a series of RAQMS simulations to identify signatures from the Asian wild fires. The first simulation, which did not include ozone or aerosol assimilation but included all Asian wildfire emissions, is referred to as the "baseline" simulation. We then conducted a series of RAQMS simulations where we restricted April 2008 wildfire emissions to within the Kazakhstan, Siberian, or Thailand regions. These simulations did not include MODIS aerosol or OMI ozone assimilation so that we could assess differences in tropospheric ozone that arise due to the wildfires. These simulations included assimilation of MLS ozone profiles above $50 \mathrm{mb}$ so that stratospheric ozone was constrained for reliable estimates of the effects of stratospheric/tropospheric exchange processes. Differences between the baseline RAQMS simulation and simulations with the restricted wildfire emissions are then used to infer which fires were primarily responsible for the aerosol and tropospheric ozone enhancements observed by the DC8.

\section{RAQMS trajectory analysis}

During April 2008, MODIS fire count (Fig. 1) shows large and relatively intense wildfires taking place in Asia, particularly in Kazakhstan, Siberia and Thailand. This agrees with previous observations by the Advanced Very High Resolution Radiometer (AVHRR) over Siberia and North Asia (Cahoon et al., 1994; Tanimoto et al., 2000; Kajii et al., 2002; Kato et al., 2002) and Southeast Asia (Christopher et al., 1998; Goloub and Arino, 2000). On the 19 April, during flight 11 between Fairbanks (Alaska) and Palmdale (California), the DC8 aircraft sampled several biomass-burning plumes, as identified from in situ measurements (Fig. 2). The DC8 took off around 19:00 GMT (11:00 ADT) and landed approximately at 24:51 UTC (05:51 p.m. PDT) and remained along the OMI/TES track until around 22:51 UTC. The aircraft flew between 2 and $9 \mathrm{~km}$.

We use RAQMS chemical and aerosol analyses in conjunction with ensemble trajectory analysis (Pierce et al., 2009; Verma et al., 2009) to follow the chemical evolution of ensemble trajectories initialized at daily wildfire locations. The resulting Lagrangian photochemical histories of the wildfire plumes can be used to relate emissions from these biomass burning regions to the trace gas concentrations and location of the plumes measured by the DC8. Two plumes are examined, one plume originating from Kazakhstan and one originating from Thailand. The DC8 made in situ measurements of the Kazakhstan plume as indicated by the RAQMS trajectory analysis (Fig. 3a). This trajectory analysis indicates that the plume originates from Kazakhstan on the 7 April. After initialization, ensemble trajectories are transported eastward, in the middle troposphere, over North Asia, across the Pacific via the Bering Sea and then south of

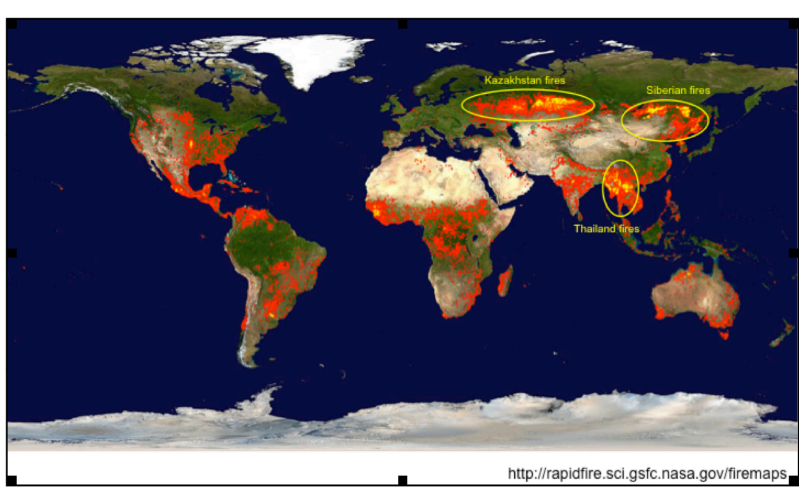

Fig. 1. April 2008 MODIS fire count.

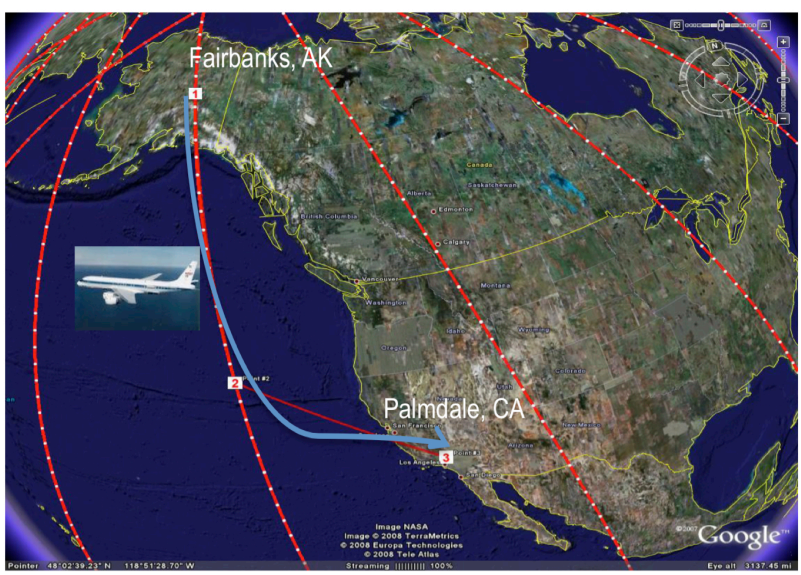

Fig. 2. Flight 11 (19 April 2008) track.

Alaska where they are intersected by the NASA/DC8 flight track on the 19 April 2008, 12.5 days after initialization. The start day was marked by a sudden increase of Kazakhstan fire $\mathrm{CO}$ emissions from less than 0.5 to more than $1.5 \mathrm{TgC} \mathrm{day}^{-1}$. During transport over Asia, the RAQMS model indicates that the wildfire plume was enhanced by Siberian biomass burning emissions with increase in $\mathrm{CO}$ and, carbonaceous aerosol (BCOC) (not shown in the figures). Moreover, the plume subsequently mixed with anthropogenic emissions over the Bering Sea, as indicated by increased $\mathrm{SO}_{4}$ concentrations in RAQMS that is consistent with aircraft $\mathrm{SO}_{2}$ measurement of approximately $450 \mathrm{pptv}$ (Fig. 7e).

Another plume identified by RAQMS forward wildfire trajectory analysis (Fig. 3b) and measured by aircraft lidar (Fig. 4) originates from Thailand on 9 April. This date matches with high Thailand fire $\mathrm{CO}$ emissions up to 3.0 $\mathrm{TgC} \mathrm{day}^{-1}$, an intensity two times higher than the Kazakhstan fire. The plume was transported eastward over China and crosses the Pacific along $40^{\circ} \mathrm{N}$ to reach NASA/DC8 flight track on 19 April 2008, 10 days after emission. 


\section{5-day Forward Trajectories Initialized 2008040712}

(Kazakhstan Wildfires within DC8 04/19 Domain)
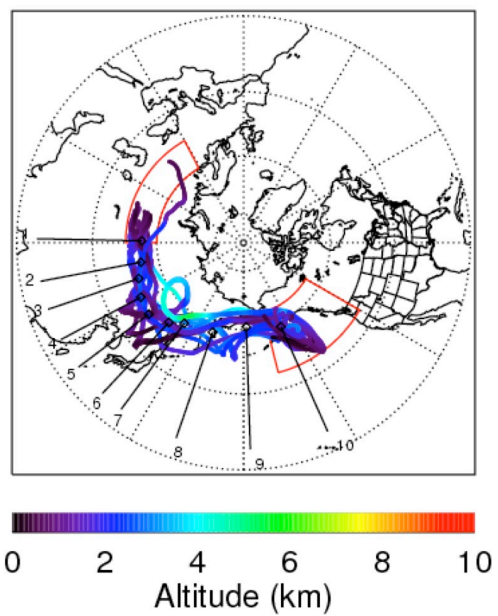

10-day Forward Trajectories Initialized 2008040912

(Thailand Wildfires within DC8 04/19 Domain)

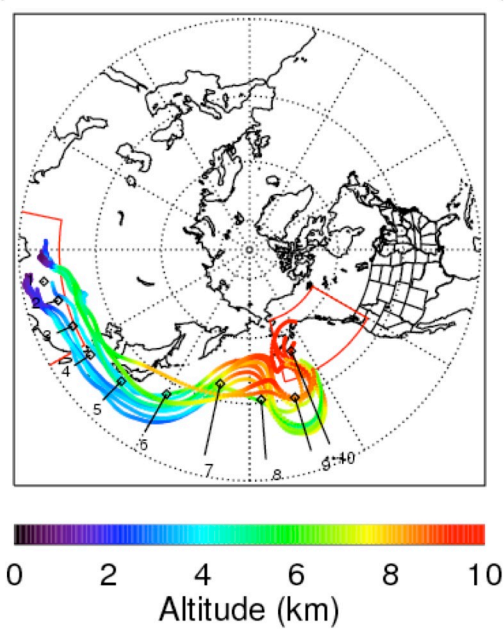

Fig. 3. (a) RAQMS Trajectories from Kazakhstan Plume and (b) Siberian Plume.

Several studies (Bey et al., 2001; Jacob et al., 2003) have already shown that $\mathrm{CO}$ from biomass burning in Southeast Asia is transported over the Pacific by the particularly strong Asian outflow in spring. The frequent cyclogenesis off the coast of East Asia transport pollution to the free troposphere (Stohl, 2001; Liu et al., 2003; Miyazaki et al., 2003) where air masses are isolated from the surface. Then, plumes are transported to northern high latitudes and divided into northern and southern branches. The plume that originated from Thailand was transported over China and the RAQMS model suggested no enhancement by anthropogenic emissions.

\subsection{Overview of DC8 aircraft in situ data during flight 11 (19 April 2008)}

\subsubsection{DIfferential Absorption Lidar (DIAL)}

During DC8 flight 11, the DIfferential Absorption Lidar (DIAL) instrument measured elevated concentrations of $\mathrm{O}_{3}$ and aerosols in what appeared to be two biomass burning plumes (Figs. 4 and 5). Figure 4 shows Aerosol Scattering Ratio (ASR) profiles measured by DIAL during DC8 flight 11 as a function of UTC time, latitude and longitude. The ASR is defined as the ratio of the attenuated aerosol backscatter laser light to the calculated molecular backscatter expected from an aerosol free atmosphere (Browell, 2001).

Values of ASR (591 nm) ranging from 0.1 to 5.0 and showing high concentrations of aerosols were observed in the lower and middle troposphere ( 2 to $6 \mathrm{~km}$ ) all along the flight track. Forward model trajectories from the wildfire locations (Sect. 2.3.1) indicate that this plume originated primarily from the Kazakhstan and Baikal fires with contributions from anthropogenic emissions. In the same way, aerosols were detected in the upper troposphere ( 8 to $12 \mathrm{~km}$ ) between 45 and 55 degrees of latitude North. Forward model trajectories from the wildfire locations (Sect. 2.3.1) indicate that this plume came from the Thailand fires. Both middle and upper tropospheric plumes showed enhanced ozone concentrations relative to the background as seen in Fig. 5. In the same figure, $\mathrm{O}_{3}$ concentrations higher than $125 \mathrm{ppbv}$ are observed in the upper troposphere around 56 degrees of latitude north (20:00 UTC time). This is the result of a stratospheric air mass descent and is not due to wildfires.

\subsubsection{In situ measurements of plume chemical composition}

The NASA DC8 aircraft flew through two parts of the lowermiddle tropospheric fire plume between $55^{\circ} \mathrm{N}$ and $50^{\circ} \mathrm{N}$ (20:10 to 21:10 UTC) and around $40^{\circ} \mathrm{N}$ (around 23:00 UTC). Unfortunately, no in situ sampling of the high altitude tropospheric plume was performed. Figure 6 shows $\mathrm{O}_{3}$, $\mathrm{CO}, \mathrm{BC}, \mathrm{NO}_{\mathrm{x}}, \mathrm{SO}_{2}$ and PAN concentrations along the DC8 flight track as a function of UTC time (from top left to bottom right panel). Each graph is color coded with HCN concentrations, a well-known fire tracer, and compared to RAQMS reanalysis at same location. As shown by the HCN color coding with $\mathrm{HCN}$ higher than 1500 pptv (green to red colors), the lower/middle tropospheric biomass burning plume which originated from Kazakhstan, was sampled twice between 20:10 and 21:10 UTC, and around 23:00 UTC. Both periods show high $\mathrm{CO}, \mathrm{SO}_{2}, \mathrm{BC}$ and PAN levels. The high levels of CO (Roths and Harris, 1996; Jaffe et al., 1997, Yurganov et al., 1998; Ponchanart et al., 2003; Fisher et al., 2010) and aerosols (Haywood and Boucher, 2000; Zhao et al., 2002; Eck et al., 2003; Myhre et al., 2003; Massie e al., 2004, Abel et al., 2005; Reid et al., 2005a, b; Forster et al., 


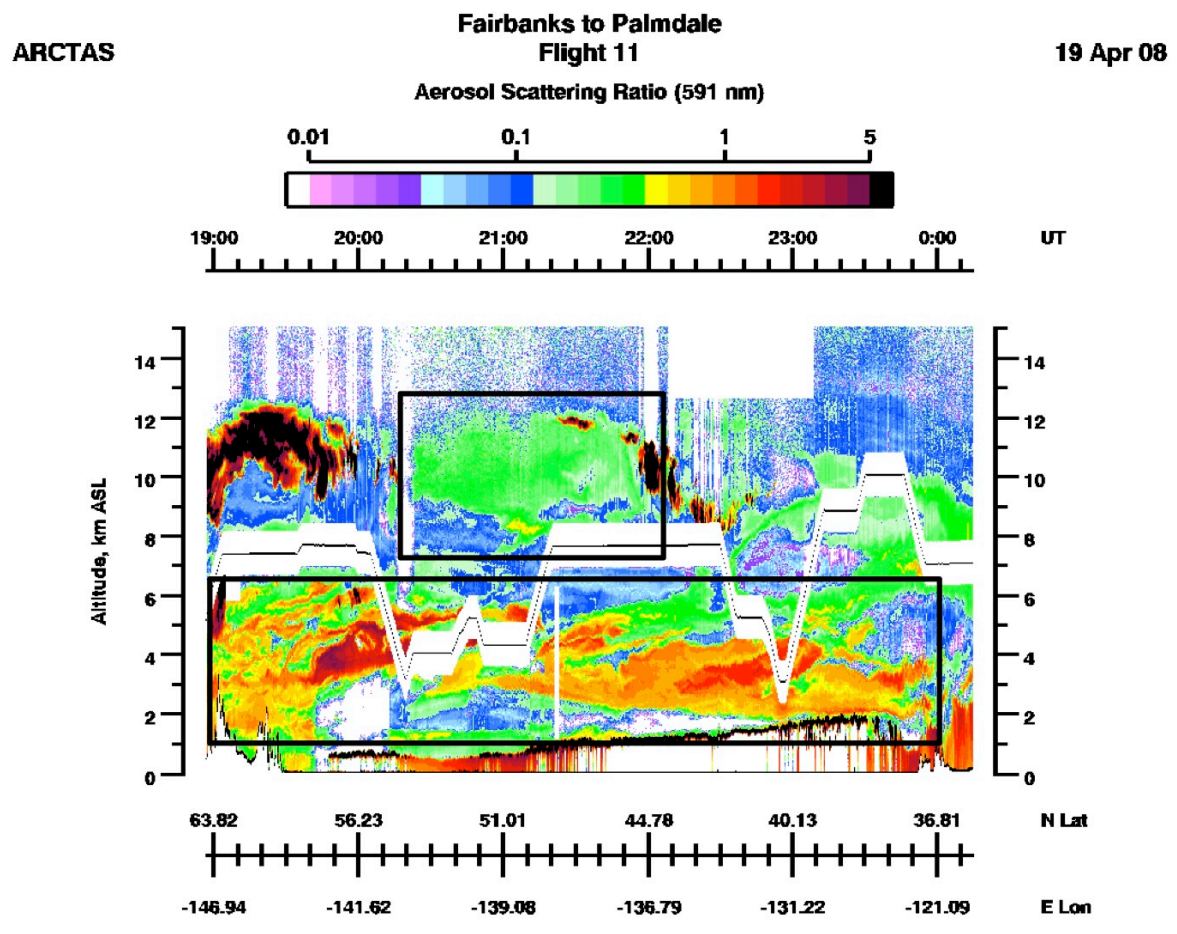

Fig. 4. Aerosol Scattering Ratio (ASR) from the Differential Analysis Lidar during DC8 flight 11 and square limiting aerosol plumes.

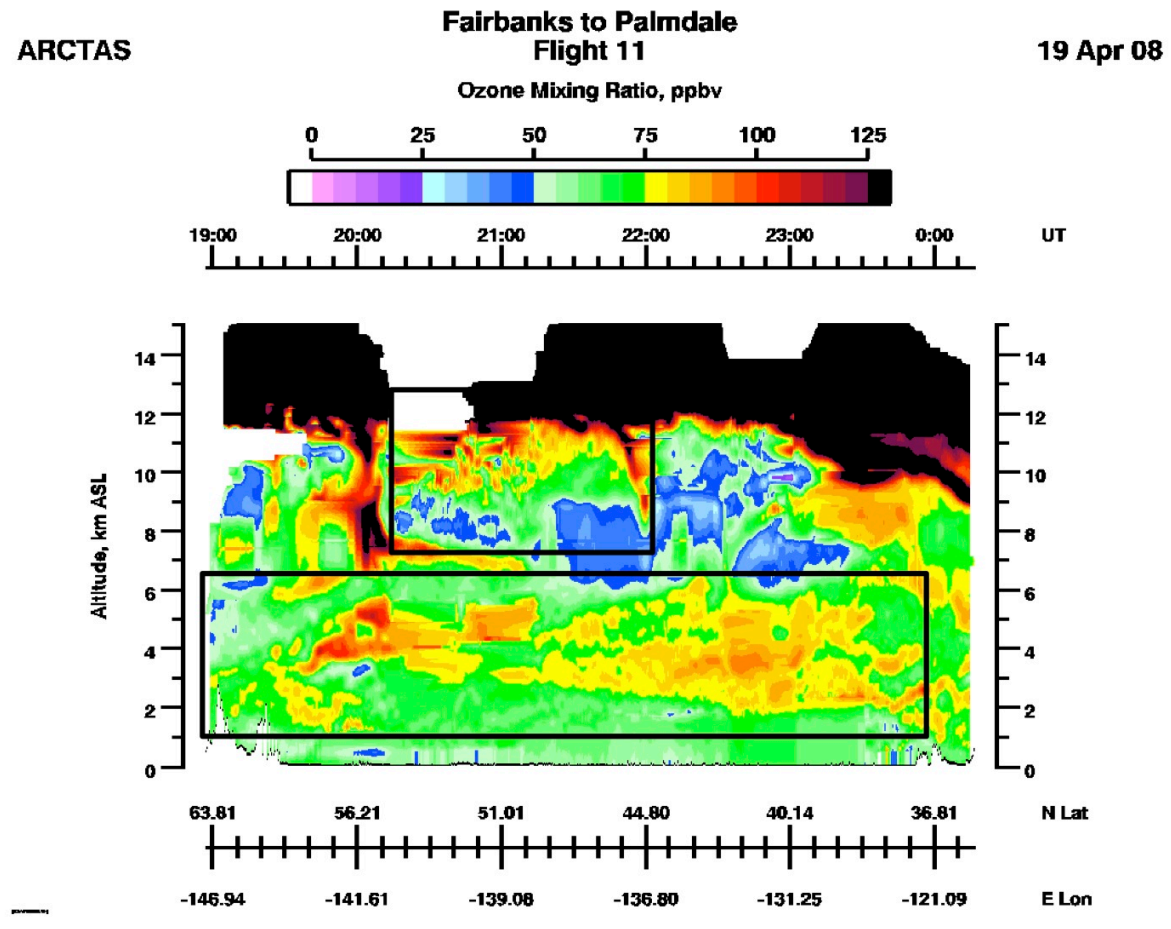

Fig. 5. Differential Analysis Lidar ozone $\left(\mathrm{O}_{3}\right)$ mixing ratio. The rectangles indicate the two ozone plumes. 

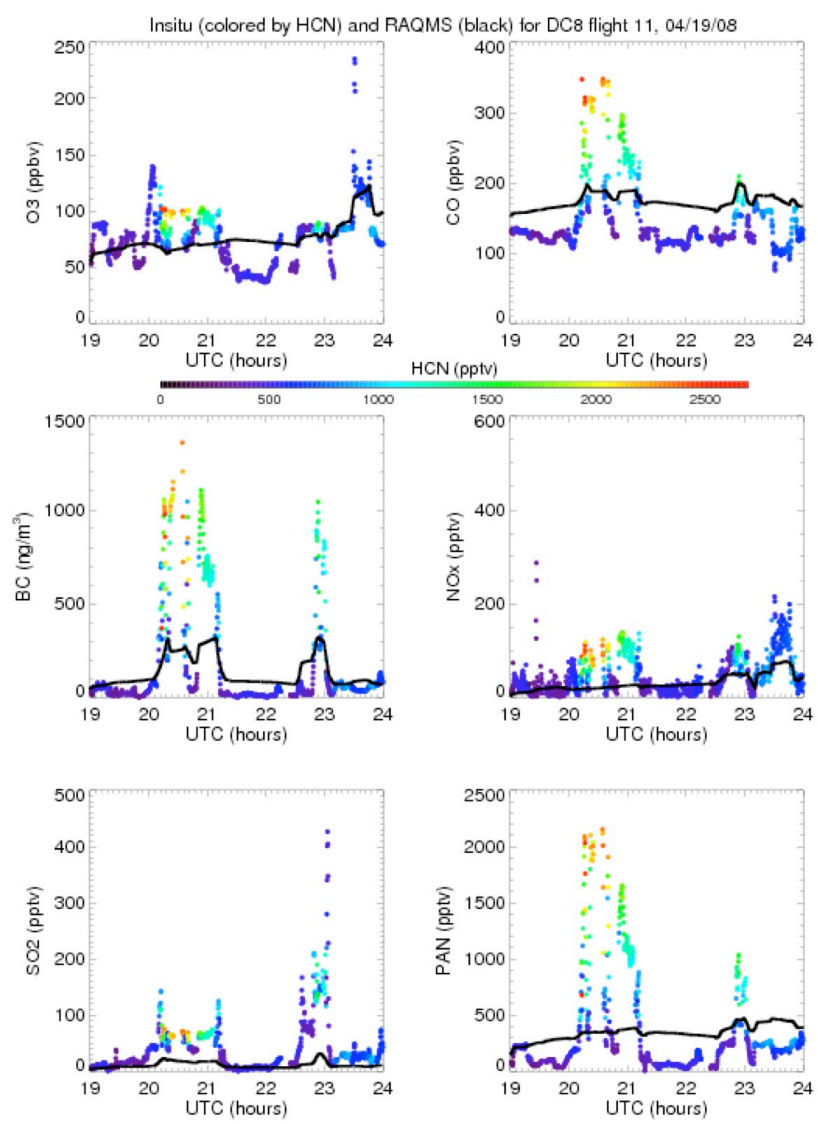

Fig. 6. Ozone $\left(\mathrm{O}_{3}\right)$, Carbon monoxide (CO), Black Carbon (BC), Nitrogen Oxides $\left(\mathrm{NO}_{\mathrm{x}}\right)$, Sulfur dioxide $\left(\mathrm{SO}_{2}\right)$ and and Peroxyacetyl Nitrate (PAN) in situ measurement colored by Hydrogen Cyanide (HCN) concentrations as a function of UTC time during DC8 flight 11 .

2007) along with high levels of HCN observed by in situ data validate the biomass burning origin of the plumes. Moreover, $\mathrm{SO}_{2}$ measurements are significantly above background levels in both part of the lower/middle tropospheric plume; these enhanced amounts suggest mixing of the biomass burning plume with anthropogenic pollution.

The top left panel of Fig. 6 shows $\mathrm{O}_{3}$ concentrations as high as $100 \mathrm{ppbv}$ in the northern part and $85 \mathrm{ppbv}$ in the southern part of the plume. These high ozone concentrations are co-located with significant concentrations of PAN and $\mathrm{NO}_{\mathrm{x}}$. PAN is an important source of $\mathrm{NO}_{\mathrm{x}}$ and $\mathrm{NO}_{\mathrm{x}}$ is an important pre-cursor of ozone indicating that ozone production can be sustained along the plume if there is a sufficient PAN reservoir and the plume moves to higher temperatures (Mauzerall et al., 1998; Real et al., 2007).

Comparisons between the RAQMS analysis (black lines in Fig. 6) and in situ measurements from the DC8 on 19 April show that the elevated $\mathrm{CO}, \mathrm{BC}, \mathrm{NO}_{\mathrm{x}}, \mathrm{SO}_{2}$, and PAN due to biomass burning (high $\mathrm{HCN}$ ) observed by the aircraft is underestimated in the northern part of the plume. As seen in the top panel of Fig. 7 the RAQMS model estimates of black carbon are not at the same altitude or have the same width as the elevated plume found at $4 \mathrm{~km}$ in the DIAL aerosol scattering ratio and sampled by the DC8 at this time. Instead, RAQMS shows a broader plume that is at a lower altitude. This broader plume was sampled again at its southern location, where RAQMS shows somewhat better agreement with the in situ measurements but is still low. These underestimates are a consequence of diffusive transport associated with the relatively coarse horizontal $(2 \times 2$ degrees $)$ and vertical $(0.5-1 \mathrm{~km}$ in the free troposphere) resolution of the RAQMS model. RAQMS shows no $\mathrm{NO}_{\mathrm{x}}$ enhancements in the northern part of the plume and consequently underestimates ozone production.

In summary, the aircraft data suggest that the observed plumes in the middle and lower troposphere originate from biomass burning and were subsequently mixed with anthropogenic pollution. However, RAQMS is not able to capture the plume pollutant concentrations with accuracy due to its coarse resolution. The lidar data also indicate a plume of ozone in the upper troposphere that is due to both biomass burning but potentially with a contribution from stratospheric/tropospheric exchange. We next use the aircraft data along with the forward wildfire trajectories (Sect. 2.3.1.) and $\mathrm{CO}$ and ozone profile measurements from TES as well as the RAQMS model to confirm the biomass burning origin of these plumes and explain the ozone distributions observed by the aircraft on 19 April 2008.

\section{Source identification of observed plumes}

As discussed earlier, significant wild fires occurred in western Asia (Kazakhstan), eastern Asia (Siberia) and southeastern Asia (Thailand). Satellite fire counts over Russia were more than two times the April average in April 2008 (Fisher et al., 2010). Kazakhstan and Siberian fires are mainly due to burning of mixed coniferous and deciduous forest and croplands as observed by one-degree land cover derived from AVHRR. Thailand fires are due to burning of broadleaf evergreen forest, grassland and cropland (http://glcf.umd.edu/ data/landcover/).

\subsection{Ozone origin in Asian fire plumes}

Using TES and RAQMS $\mathrm{CO}$ and $\mathrm{O}_{3}$ profiles we observe and interpret $\mathrm{CO}$ and $\mathrm{O}_{3}$ concentrations during transport of the Kazakhstan/Siberian and the Thailand plumes from emission to flight location. We also discuss the impact of fire emissions and stratospheric-tropospheric exchange on $\mathrm{O}_{3}$ concentrations.

\subsubsection{Kazakhstan and Siberian fires}

We first examine the Kazakhstan plume $\mathrm{CO}$ and $\mathrm{O}_{3}$ concentrations at different locations during transport across the 

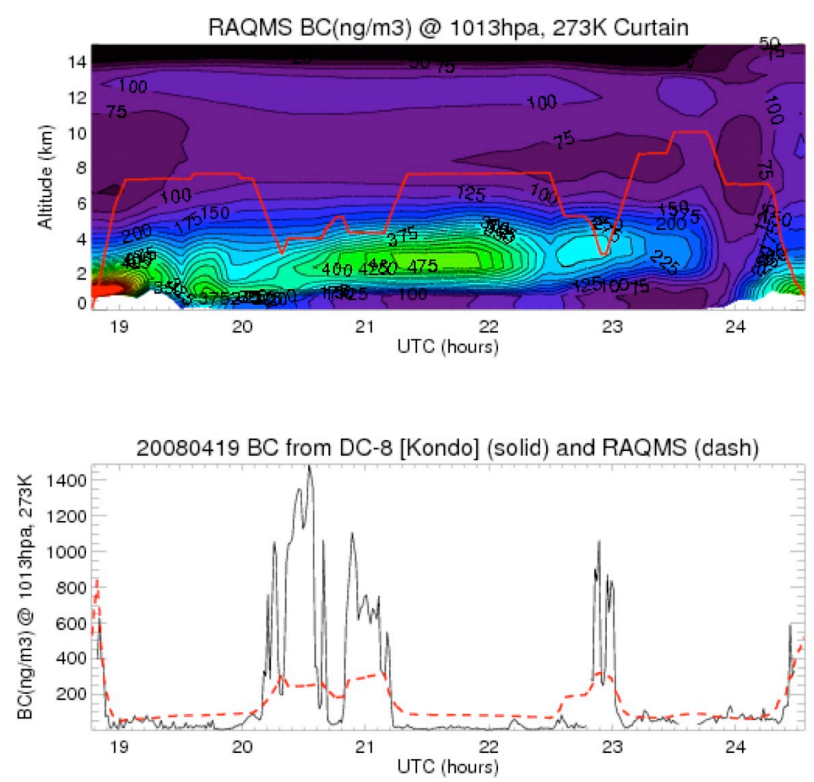

Fig. 7. RAQMS Black Carbon (BC) profile and comparison between RAQMS (dotted line) and in situ (solid line) BC concentrations during DC8 flight 11.

Pacific using the TES data and RAQMS chemical analyses. RAQMS ensemble trajectory analysis is used to determine which TES profiles sampled the wildfire plumes and we use TES and RAQMS $\mathrm{CO}$ and $\mathrm{O}_{3}$ profiles to characterize the plume chemical and dynamical evolution and the observed versus modeled variability of ozone and $\mathrm{CO}$ concentrations in the plume. Table 1 shows dates, locations and UTC time of each TES wildfire plume profile used during the study.

Ozone and $\mathrm{CO}$ concentrations are examined in three locations as shown in Fig. 8a through c. First, we observe $\mathrm{O}_{3}$ and $\mathrm{CO}$ concentrations in the plume on 7 April 2008 over Kazakhstan. Then, we examine the plume evolution using its $\mathrm{CO}$ and ozone relationship at an intermediate location over Siberian fires 14 April 2008. Finally, we examine the plume $\mathrm{O}_{3}$ and $\mathrm{CO}$ concentrations close to NASA/DC8 flight location and date 18 April 2008.

Tropospheric concentrations of $\mathrm{CO}$ are plotted against ozone using estimated concentrations from the TES profiles over the Kazakhstan fire in the top left panel of Fig. 8a. Tropospheric CO and ozone concentrations from RAQMS chemical analysis are plotted in the bottom right panel of Fig. 8a. Although the TES estimates of any individual pressure level in any profile is dependent on the a priori used to regularize the TES profile retrievals, applying the instrument operator (which is dependent on the a priori constraint and the averaging kernel, or retrieval sensitivity to true state) to the model will remove the effect of the a priori and sensitivity in the comparison; the comparison will then show if the model is overestimating the variability of ozone or $\mathrm{CO}$ and/or whether the correlation between ozone and $\mathrm{CO}$ in the

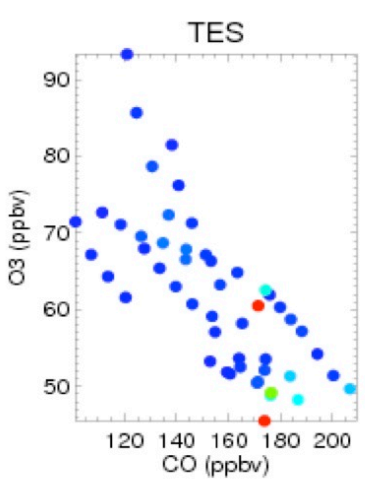

Kazakhstan Plume 2008/04/7
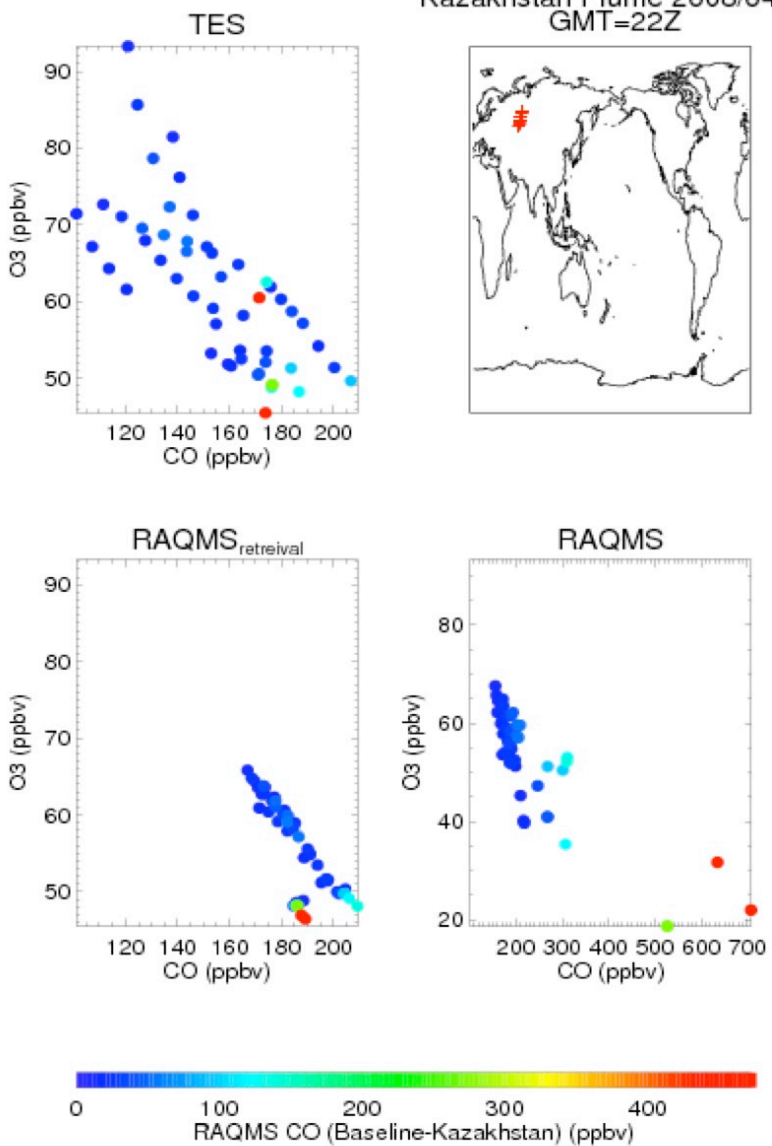

Fig. 8a. (Top left) TES ozone and CO over Kazakhstan fires. (Top right) TES measurement locations. (bottom right) RAQMS estimates of CO and ozone. (Bottom left) RAQMS estimates of CO and Ozone after applying TES a priori and averaging kernel to RAQMS estimates.

data is consistent with the model (e.g. Zhang et al., 2006). If the ozone/CO variability from the model is consistent with the TES estimate after having applied the instrument operator then our conclusion would be that the model estimate of the ozone/CO variability and correlation is reasonable within the TES errors.

The bottom left panel shows these same RAQMS concentrations after the TES averaging kernel and constraint vector have been applied to account for the TES vertical sensitivity and retrieval bias (e.g. Jones et al., 2003; Pierce et al. 2009; Worden et al., 2004; Bowman et al., 2002, 2006, 2009) which will be referred to as the "adjusted" RAQMS model. The $\mathrm{CO} / \mathrm{O}_{3}$ scatter plots are color-coded by the predicted $\mathrm{CO}$ enhancement associated with the Kazakhstan wildfires, as determined by the differences between the RAQMS baseline and no Kazakhstan wildfire emission simulations. Colorcoding helps to indicate the impact of Kazakhstan fire emissions on RAQMS and TES CO and $\mathrm{O}_{3}$. In all graphs, green to 


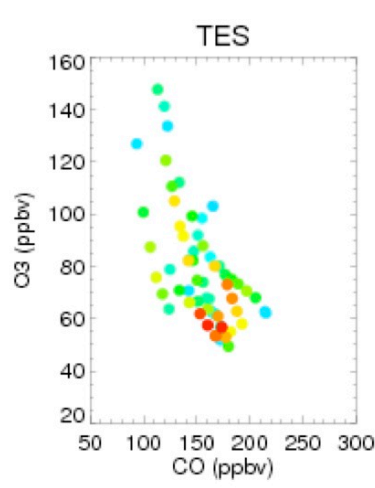

Kazakhstan Plume 2008/04/14
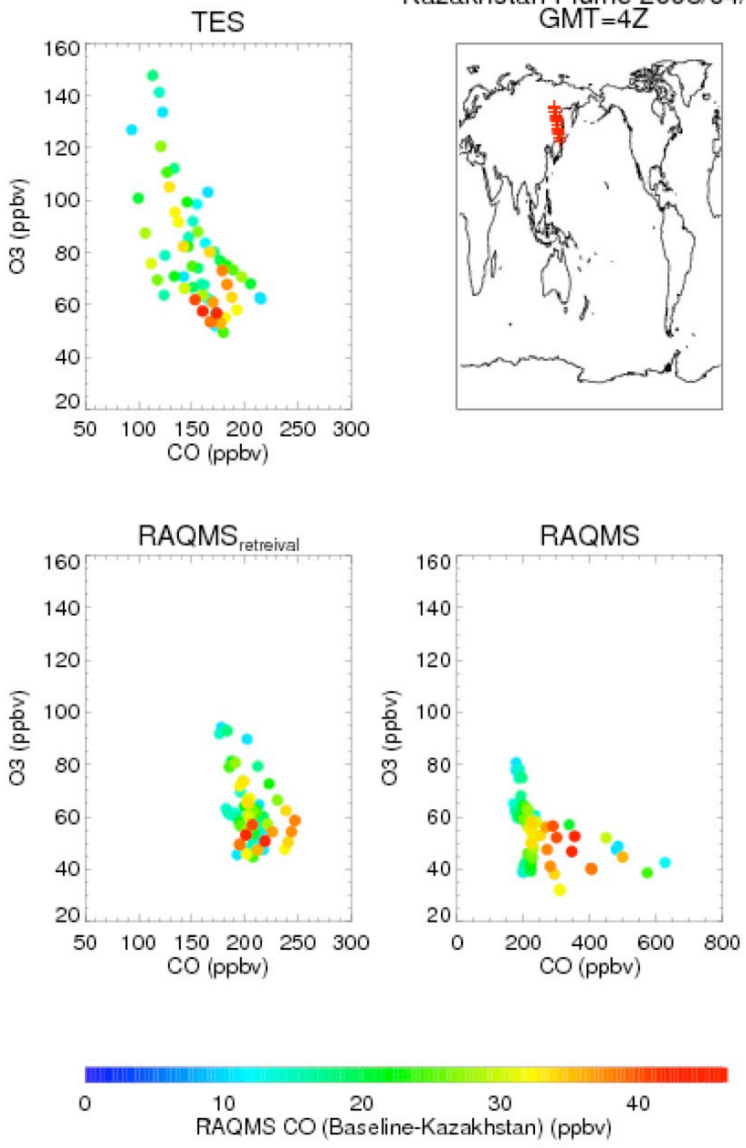

Fig. 8b. Same as in Fig. 8a but over Siberia.

Table 1. Dates, locations and UTC time of each TES profile used during the Kazakhstan/Siberian wildfire plume study.

\begin{tabular}{llll}
\hline Date & Mean latitude & Mean longitude & UTC time \\
\hline $04 / 07 / 08$ & $56^{\circ} \mathrm{N}$ & $85^{\circ} \mathrm{E}$ & $20: 45$ \\
$04 / 10 / 08$ & $55^{\circ} \mathrm{N}$ & $100-105^{\circ} \mathrm{E}$ & $06: 05$ \\
$04 / 11 / 08$ & $50^{\circ} \mathrm{N}$ & $115^{\circ} \mathrm{E}$ & $18: 40$ \\
$04 / 12 / 08$ & $52^{\circ} \mathrm{N}$ & $130^{\circ} \mathrm{E}$ & $04: 15$ \\
$04 / 14 / 08$ & $52^{\circ} \mathrm{N}$ & $135-140^{\circ} \mathrm{E}$ & $04: 00$ \\
$04 / 16 / 08$ & $55^{\circ} \mathrm{N}$ & $175-180^{\circ} \mathrm{W}$ & $00: 30$ \\
$04 / 16 / 08$ & $55^{\circ} \mathrm{N}$ & $160-165^{\circ} \mathrm{W}$ & $23: 30$ \\
$04 / 17 / 08$ & $57^{\circ} \mathrm{N}$ & $155^{\circ} \mathrm{W}$ & $13: 00$ \\
$04 / 18 / 08$ & $55^{\circ} \mathrm{N}$ & $150^{\circ} \mathrm{W}$ & $23: 25$ \\
\hline
\end{tabular}

red points show high Kazakhstan fire influence on RAQMS CO concentrations.

The initial comparison between TES and adjusted RAQMS (left side of Fig. 8a) shows good agreement in maximum $\mathrm{CO}$ (which is associated with the wildfire plume) but RAQMS shows larger minimum CO (160 ppbv vs. $110 \mathrm{ppbv})$. This is due to overestimates in RAQMS back-

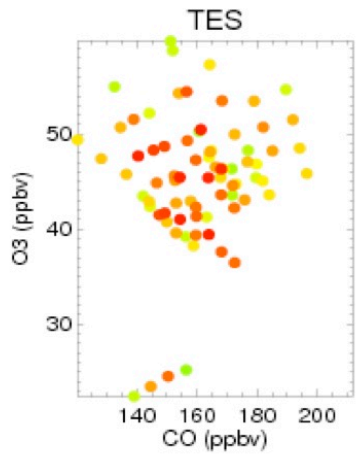

Kazakhstan Plume 2008/04/18
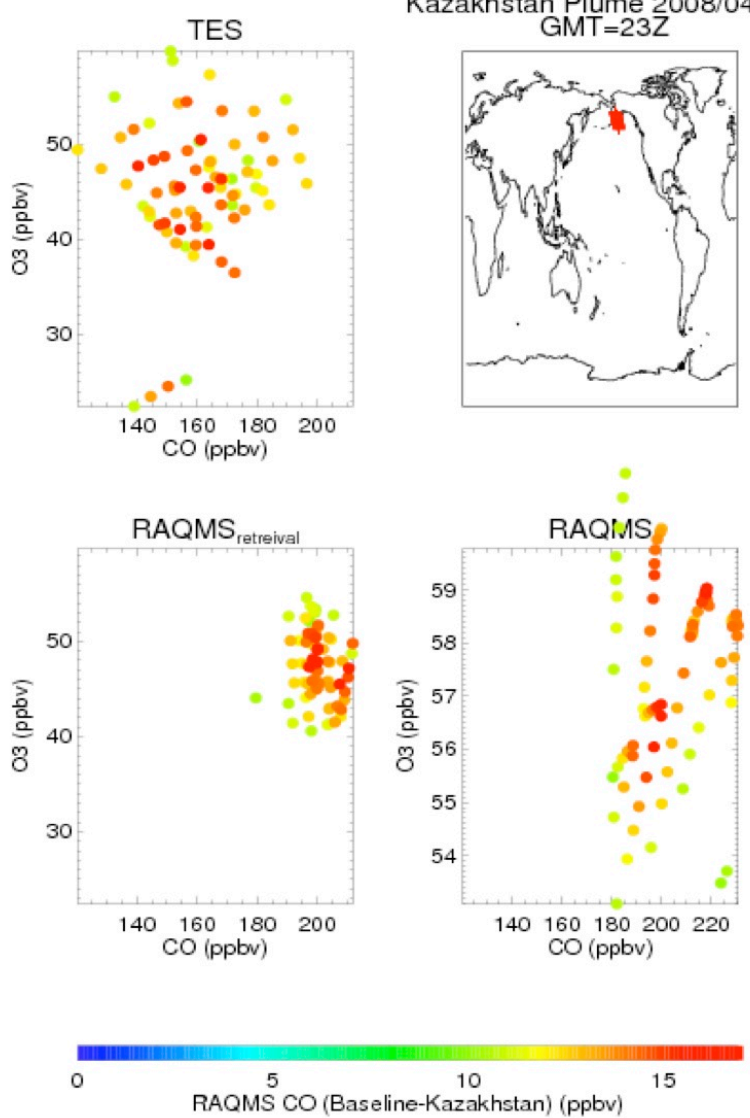

Fig. 8c. Same as Figs. 8a and b but near the DC9 measurements.

ground $\mathrm{CO}$ mixing ratios that increase with latitude in the Northern Hemisphere (also evident in the comparison with in situ measurements on 19 April (Fig. 6b). RAQMS ozone initially (7 April) ranges from $45-65$ ppbv which is in agreement with TES except for a few points with $\mathrm{O}_{3}$ between 70 and 90 ppbv (also evident on 14 April, Fig. 8b). These retrieved ozone enhancements are found in the upper troposphere in the TES retrieval and not associated with the Kazakhstan wildfire plume and indicate underestimates in stratospheric-tropospheric exchange in RAQMS relative to the TES retrievals. As shown by RAQMS, the magnitude of the wildfire $\mathrm{CO}$ enhancement for this plume could be as high as 600-700 ppbv on 7 April (see lower right in Fig. 8a). The negative correlation between $\mathrm{O}_{3}$ and $\mathrm{CO}$ suggests that the majority of the sampled air may have originated from the stratosphere. Therefore, for TES observations over Kazakhstan source region (Fig. 8a), elevated $\mathrm{O}_{3}$ is mainly due to stratospheric enhancements and wildfire emissions are not observed to significantly contribute to $\mathrm{O}_{3}$ enhancements within the plume. This can be due to the fact that the plume sampling occurs right after plume emission and does not allow a sufficient time for $\mathrm{O}_{3}$ precursors to react in the troposphere and produce $\mathrm{O}_{3}$. 
After emission, the Kazakhstan wildfire plume was transported eastward in the middle troposphere $(\sim 500 \mathrm{hPa})$ over Asia. Before reaching the Pacific, the plume encountered fire emissions from Siberia (Baikal) (Fig. 8b) leading to additional $\mathrm{CO}$ enhancements (up to $600 \mathrm{ppbv}$ ) that were not associated with the initial Kazakhstan emissions (bottom right panel of Fig. 8b). TES and the adjusted RAQMS model agree in the estimation of maximum $\mathrm{CO}$ concentration (respectively $220 \mathrm{ppbv}$ and $250 \mathrm{ppbv}$ ) that are associated with the wildfire emissions. However, the adjusted RAQMS model shows higher background CO concentrations than TES by more than 70ppbv. The adjusted RAQMS model underestimates maximum $\mathrm{O}_{3}$ concentrations observed by TES by more than $50 \mathrm{ppbv}$ due to errors in representation of stratospheric/tropospheric exchange in the RAQMS model due to the relatively coarse horizontal and vertical resolution.

As suggested by the aircraft in situ $\mathrm{SO}_{2}$ measurements (Sect. 2.2.2) and confirmed by the RAQMS analysis of the Lagrangian chemical evolution of the Kazakhstan wildfire plume (not shown here), the plume mixed with Asian anthropogenic emissions. The plume was then transported in the middle troposphere over the Pacific via the Bering Sea and reached flight location around 18 April (Fig. 8c). Both TES and the adjusted RAQMS model show similar maximum $\mathrm{CO}$ concentrations (around $225 \mathrm{ppbv}$ ) and $\mathrm{O}_{3}$ concentrations ( $\max \mathrm{O}_{3}=60 \mathrm{ppbv}, \min \mathrm{O}_{3}=40 \mathrm{ppbv}$ ). In contrast, in situ measurements within the wildfire plume from flight 11 give $\mathrm{O}_{3}$ concentrations ranging from 80 to $100 \mathrm{ppbv}$ in the plume (black dots in Fig. 9). Investigation of TES and MODIS cloud data show that there is high cloud density over the region where the DC8 sampled the main part of the plume. As a result, TES shows little sensitivity in $\mathrm{O}_{3}$ between 50 and $60^{\circ} \mathrm{N}$. Background $\mathrm{CO}$ concentrations are still overestimated by the adjusted RAQMS model by more than 60 ppbv compared to TES CO (Fig. 8c), which is consistent with the comparisons with in situ CO in Fig. 9. Finally, TES shows a low $\mathrm{O}_{3}$ event, down to $20 \mathrm{ppbv}$ of $\mathrm{O}_{3}$, which is not captured by the adjusted RAQMS model (Fig. 8c). Figure 9 shows in situ measurements onboard the DC8 aircraft with higher concentrations of $\mathrm{O}_{3}$ ranging from 60 to $120 \mathrm{ppbv}$ collocated with $\mathrm{CO}$ over $150 \mathrm{ppbv}$ (pink dots) and a positive $\mathrm{O}_{3} / \mathrm{CO}$ correlation showing $\mathrm{O}_{3}$ production in the plume. In addition, the background air shows a negative correlation of low $\mathrm{CO}$ with high ozone indicated stratospheric influence. The RAQMS model estimates are consistent with the background ozone and $\mathrm{CO}$ showing stratospheric influence on the observed ozone but does not show a positive correlation of ozone and $\mathrm{CO}$ in the wildfire plume. We attribute this discrepancy to transport errors in the RAQMS model and the narrowness of the plume feature which result in difficulty in modeling the photochemical production of ozone within the plume.

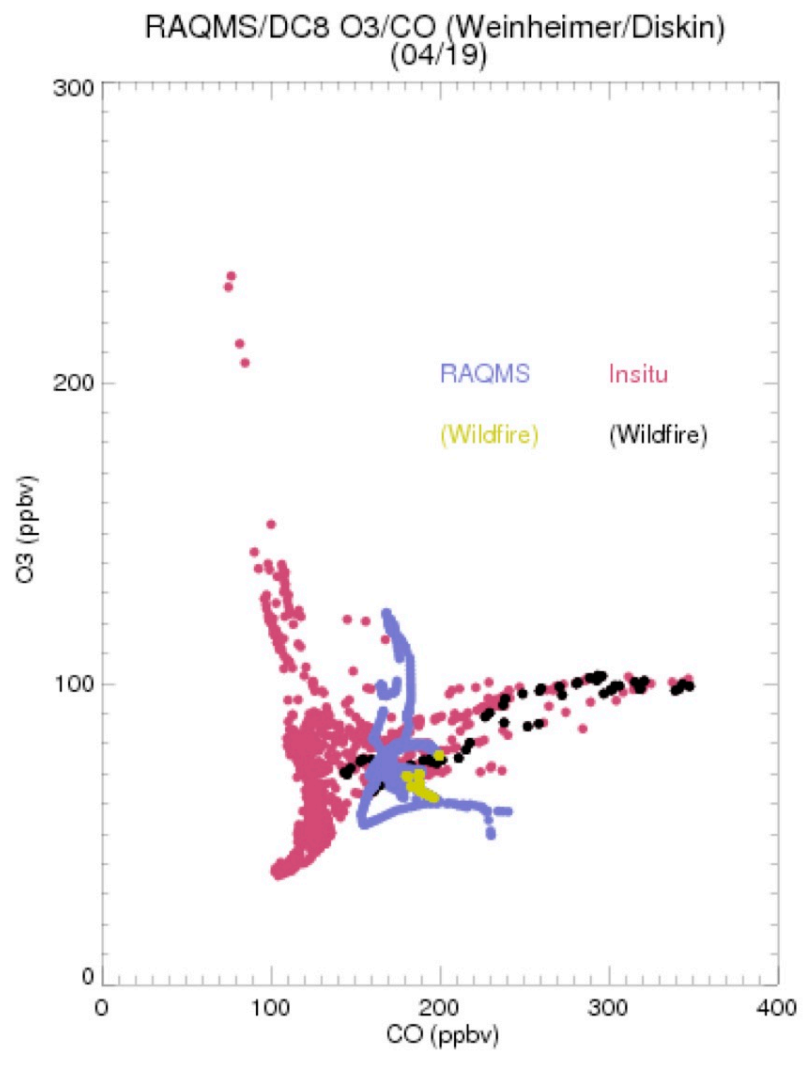

Fig. 9. Carbon monoxide (CO) (abscissa) and ozone $\left(\mathrm{O}_{3}\right)$ (ordinate) comparison of background air from the in situ data (pink dots) and RAQMS (blue dots). Wildfire influenced in situ data (black dots) and RAQMS (yellow) measurement for DC8 flight 11.

\subsubsection{Thailand fires}

We next examine the Thailand plume $\mathrm{CO}$ and $\mathrm{O}_{3}$ concentrations at different locations during transport from the source and across the Pacific where the Thailand plume was eventually observed by DIAL on the DC8. Table 2 shows dates, locations and UTC time of each TES profiles used during the study. Three steps of the plume transport are discussed. First, we observe $\mathrm{O}_{3}$ and $\mathrm{CO}$ concentrations in the plume immediately downwind of source region (Thailand) during convective lifting over the Tibetan plateau (11 April 2008). Then, we quantify plume evolution at an intermediate location over the Pacific (15 April 2008) showing strong stratospheric air masses influence. Finally, we examine plume $\mathrm{O}_{3}$ and $\mathrm{CO}$ concentrations near the NASA/DC8 flight location (19 April 2008).

Figure 10 shows vertical profiles of ozone and CO concentrations downwind of the Thailand fires. Significant CO concentrations are observed near the surface between 10 and 25 degrees latitude with higher than average $\mathrm{CO}$ concentrations in the middle/upper troposphere. The averaging kernels (averaging kernels not shown but can be referenced 

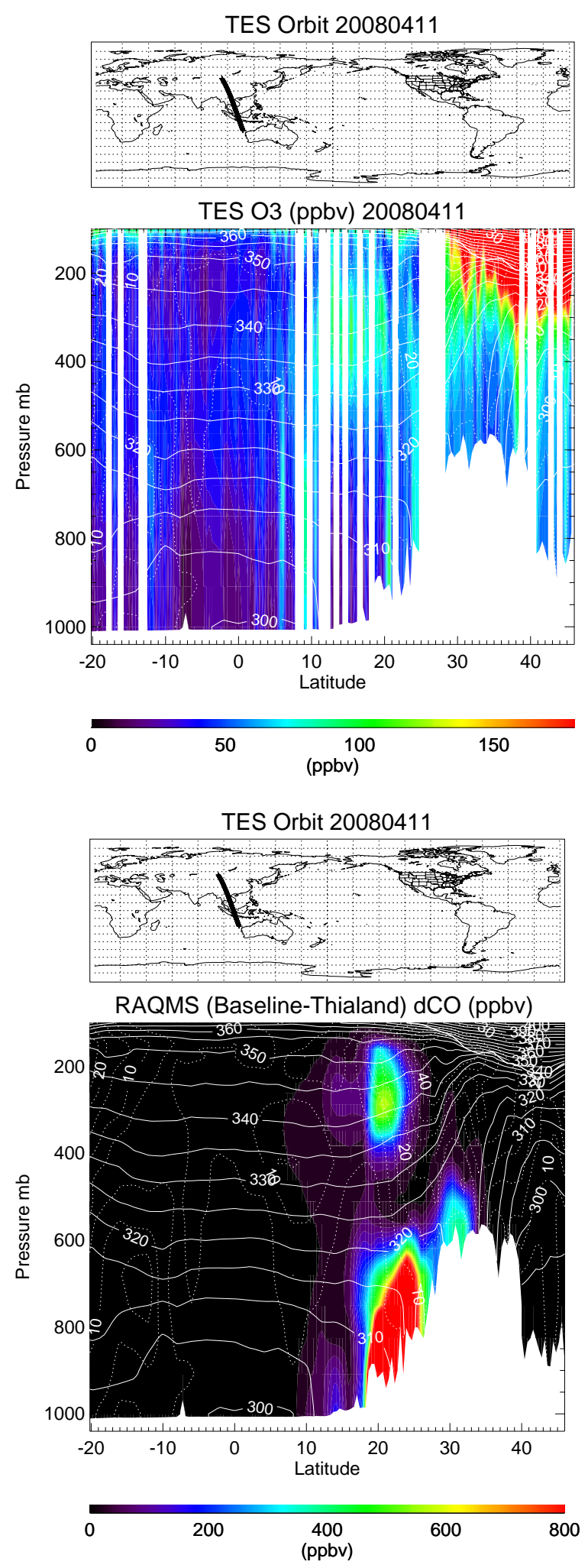

Fig. 10. (Top panel) Observed TES ozone over Thailand and south of the Himalayas. (Bottom panel) Observed TES CO.
Table 2. Dates, locations and UTC time of each TES profile used during the Thailand wildfire plume study.

\begin{tabular}{llll}
\hline Date & Mean latitude & Mean longitude & UTC time \\
\hline $04 / 09 / 08$ & 24.3 & $98.8^{\circ} \mathrm{E}$ & $06: 50$ \\
$04 / 10 / 08$ & 28 & $101^{\circ} \mathrm{E}$ & $06: 35$ \\
$04 / 11 / 08$ & 27.1 & $108.1^{\circ} \mathrm{E}$ & $18: 00$ \\
$04 / 12 / 08$ & 34.8 & $116.3^{\circ} \mathrm{E}$ & $04: 45$ \\
$04 / 14 / 08$ & 34.6 & $127.1^{\circ} \mathrm{E}$ & $05: 00$ \\
$04 / 15 / 08$ & 40.1 & $167.4^{\circ} \mathrm{E}$ & $15: 00$ \\
$04 / 17 / 08$ & 54.1 & $170.5^{\circ} \mathrm{W}$ & $13: 00$ \\
$04 / 19 / 08$ & 57.4 & $144.3^{\circ} \mathrm{W}$ & $11: 00$ \\
\hline
\end{tabular}

at: http://tes.jpl.nasa.gov/visualization/SCIENCE_PLOTS/ R11/PNG_Files/run6947/run_6947_curtain_A_CO.png) indicate sensitivity to $\mathrm{CO}$ variability between $300 \mathrm{hPa}$ and the surface and that $\mathrm{CO}$ concentrations at the surface can be distinguished from those at $400 \mathrm{hPa}$. Consequently, the TES data are consistent with the RAQMS model that indicate convective lofting of surface emissions into the upper troposphere. The TES ozone estimates (top panel) show peak values at $300 \mathrm{hPa}$ which also indicate convective lofting of ozone and ozone pre-cursors into the upper troposphere (Worden et al., 2009)

Figure $11 \mathrm{a}, \mathrm{b}$ and $\mathrm{c}$ show $\mathrm{O}_{3}$ and $\mathrm{CO}$ concentrations comparisons for the region shown in Fig. 10 and for regions downwind of the plume. As observed in the Kazakhstan/Siberian plume study, RAQMS CO downwind of source region (Fig. 11a) is higher than TES by almost a factor of 6 prior to applying the TES averaging kernel (AK) and a priori constraint. However, after application of the TES AK and a priori constraint to the RAQMS results, both ranges of variability of $\mathrm{CO}$ and Ozone are in good agreement, that is, they are within the approximately $20 \%$ random uncertainty of the TES ozone and CO estimates. The reduced variability of the TES estimates to $\mathrm{CO}$ in the upper troposphere is due to the reduced sensitivity of the TES measurement to $\mathrm{CO}$ at these altitudes (Worden et al., 2004). Because of the consistency of the adjusted RAQMS estimates and the TES estimates, we conclude that the upper tropospheric $\mathrm{O}_{3}$ concentrations observed by TES are likely due to both stratospheric enhancement and photochemical $\mathrm{O}_{3}$ produced from Thailand fires $\mathrm{O}_{3}$ precursors. The color-coding shows that most of the plume is influenced by $\mathrm{CO}$ emissions from fires $(d \mathrm{CO}>150 \mathrm{ppbv})$. However, for $\mathrm{CO}$ concentrations under $100 \mathrm{ppbv}$ (TES) and $d \mathrm{CO}$ under $100 \mathrm{ppbv}$, we notice highest $\mathrm{O}_{3}$ concentrations up to $320 \mathrm{ppbv}$ for TES and only 240 ppbv for the adjusted RAQMS model due to underestimation of the stratospheric-tropospheric exchange. As shown by Fig. 12a and b, downwind of the Thailand fires, part of the Thailand plume is located in the upper troposphere over the Tibetan plateau $\left(20-25^{\circ} \mathrm{N}\right)$ where it is most 


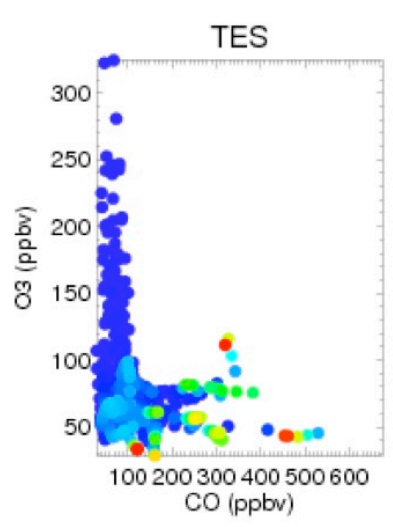

Thailand Plume 2008/04/11
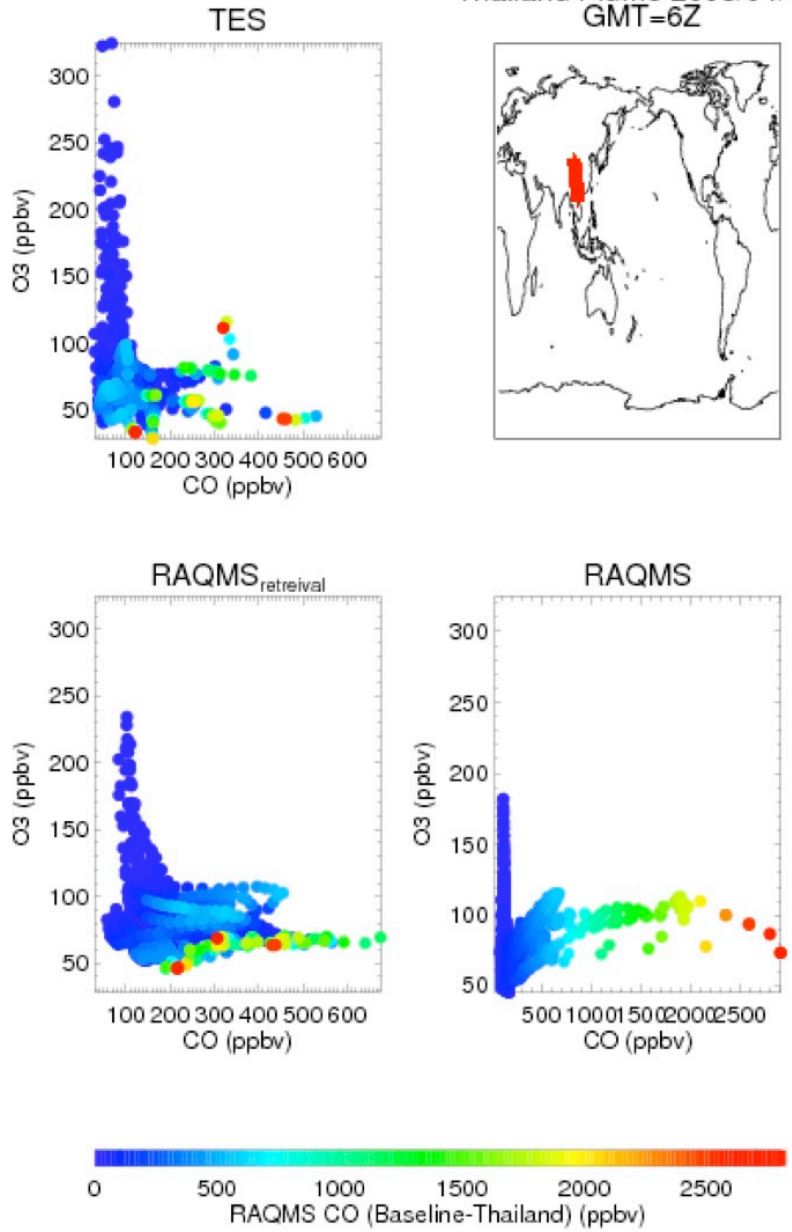

Fig. 11a. Same as Fig. 8 but near source region for Thailand Fires.

likely to mix with stratospheric air masses. Figure $12 \mathrm{a}$ and b show $d \mathrm{O}_{3}$ and $d \mathrm{CO}$ concentration perturbations due the Thailand fires predicted by the RAQMS model. It allows a better representation of the plume position and elevation in that it distinguishes the plume from what is expected from stratospheric/tropospheric exchange. The RAQMS model estimates that up to $60 \mathrm{ppbv}$ of $\mathrm{O}_{3}$ and ppbv of $\mathrm{CO}$ are due to the Thailand fires. In Fig. 12a and b, $\mathrm{O}_{3}$ enhancements are observed within the upper tropospheric portion of the Thailand plume consistent with the TES measurements (Fig. 10). RAQMS $\mathrm{O}_{3}$ concentrations respectively up to $120 \mathrm{ppbv}$ and $110 \mathrm{ppbv}$ and a positive slope shows photochemical production within the plume.

The plume was then transported in the free troposphere over the Pacific. The distributions of $\mathrm{CO}$ and $\mathrm{O}_{3}$ are shifted and show increased mixing between stratospheric and photochemically produced $\mathrm{O}_{3}$ (Fig. 10b). High fire influence and photochemical production (green to red points) leads to $\mathrm{O}_{3}$ concentrations between 50 and 100 ppbv whereas stratospheric air masses (blue points) correspond to highest $\mathrm{O}_{3}$

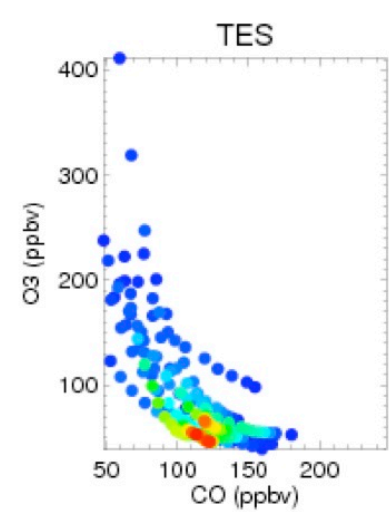

Thailand Plume 2008/04/15 $\mathrm{GMT}=15 \mathrm{Z}$
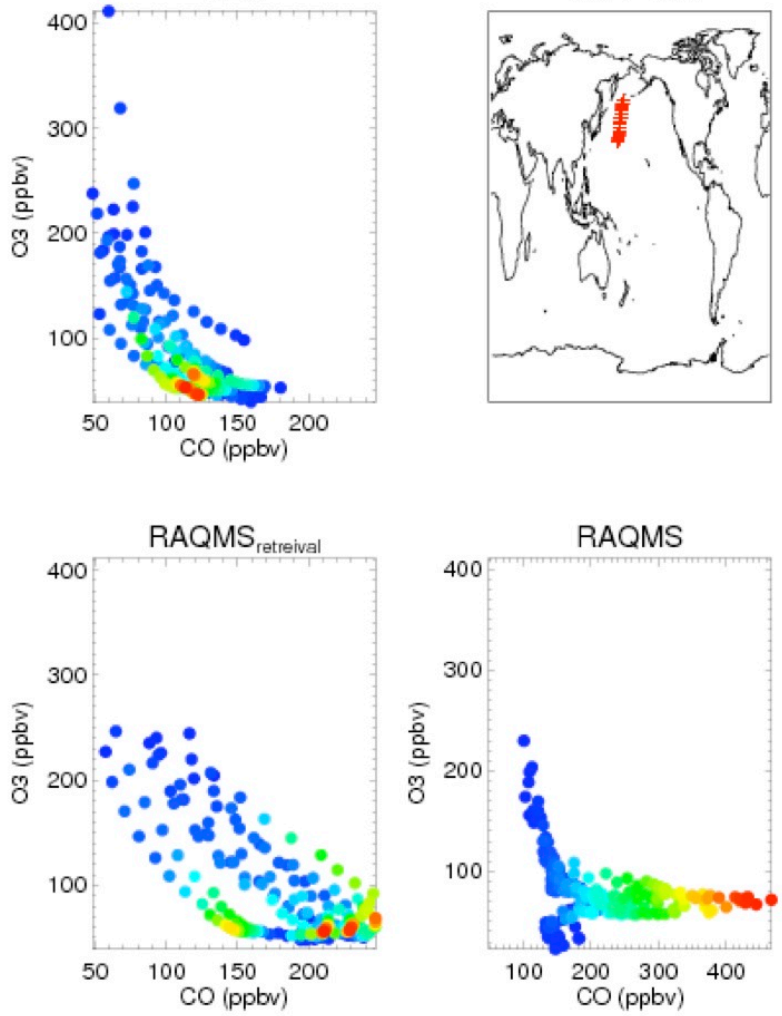

0

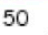

$\begin{array}{cccc}100 & 150 & 200 & 250 \\ \text { RAQMS CO (Baseline-Thailand) (ppbv) }\end{array}$

300

Fig. 11b. Same as Fig. 11a but downwind of Thailand plume.

concentrations simulated by the adjusted RAQMS model ( $260 \mathrm{ppbv}$ ) and measured by TES (400 ppbv).

The plume reached the flight location on 19 April. At flight location, TES and the adjusted RAQMS model give $\mathrm{O}_{3}$ concentrations ranging from 50 to almost $420 \mathrm{ppbv}$ (Fig. 10c). Lowest CO concentrations are collocated with highest $\mathrm{O}_{3}$ concentrations around 400ppbv for both TES and the adjusted RAQMS model indicating the influence of stratospheric air on these air parcels. However, colorcoding shows that emissions from Thailand fires also have an influence on those high $\mathrm{O}_{3}$ concentrations. In summary, the RAQMS model (accounting for TES sensitivity) gives a good estimation of $\mathrm{O}_{3}$ concentrations compared to TES but overestimates background $\mathrm{CO}$ concentrations. Unfortunately, in situ measurements do not sample the upper tropospheric plume and therefore cannot be compared with the TES and RAQMS results. 


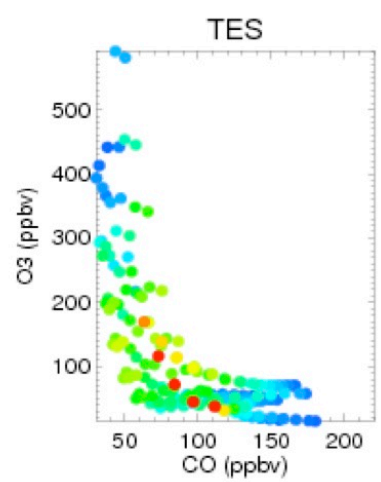

Thailand Plume 2008/04/19
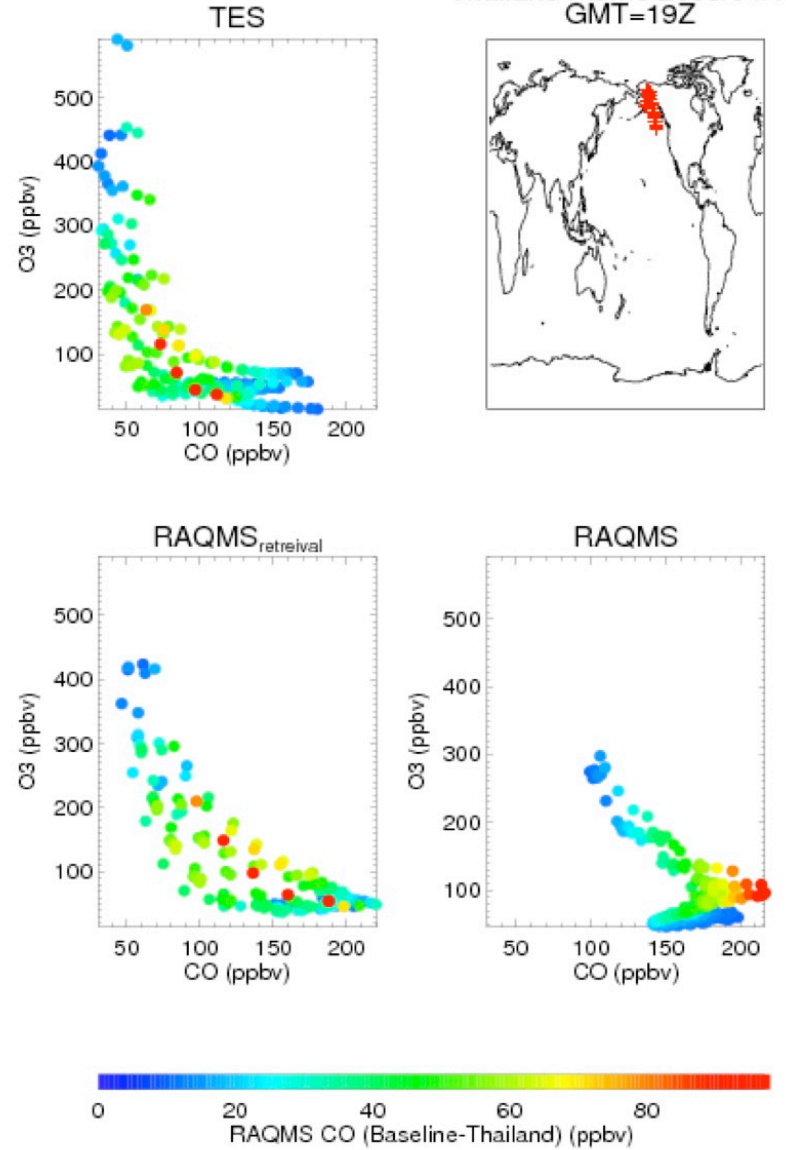

Fig. 11c. Same as Fig. 11a but near DC9 in situ measurements.

\section{Discussion}

The combination of TES and RAQMS wildfire sensitivity experiments and ensemble wildfire trajectories allows us to attribute observations of ozone and $\mathrm{CO}$ to their respective sources in Kazakhstan/Siberian and in Thailand as well as to examine the effects of convective lofting and stratospheric/tropospheric exchange on the observed ozone concentrations. We next use RAQMS sensitivity studies to quantify the impact of Asian biomass burning plumes on aerosols, $\mathrm{O}_{3}$ and $\mathrm{CO}$ sampled by the DC8. For these studies the emissions from each fire are set to zero and the ozone and $\mathrm{CO}$ concentrations are then compared to the run in which the emissions are non-zero. Note that for these sensitivity studies we do not use the RAQMS simulation with assimilated column ozone from OMI because the OMI analysis increment (which affects the entire model profile) would influence the difference in ozone and $\mathrm{CO}$ between the run without emissions and the run with emissions. We did however, retain assimilation of MLS stratospheric profiles above $50 \mathrm{mb}$ so that the influence of stratosphere/troposphere exchange processes on the wildfire plumes can be more accurately represented.
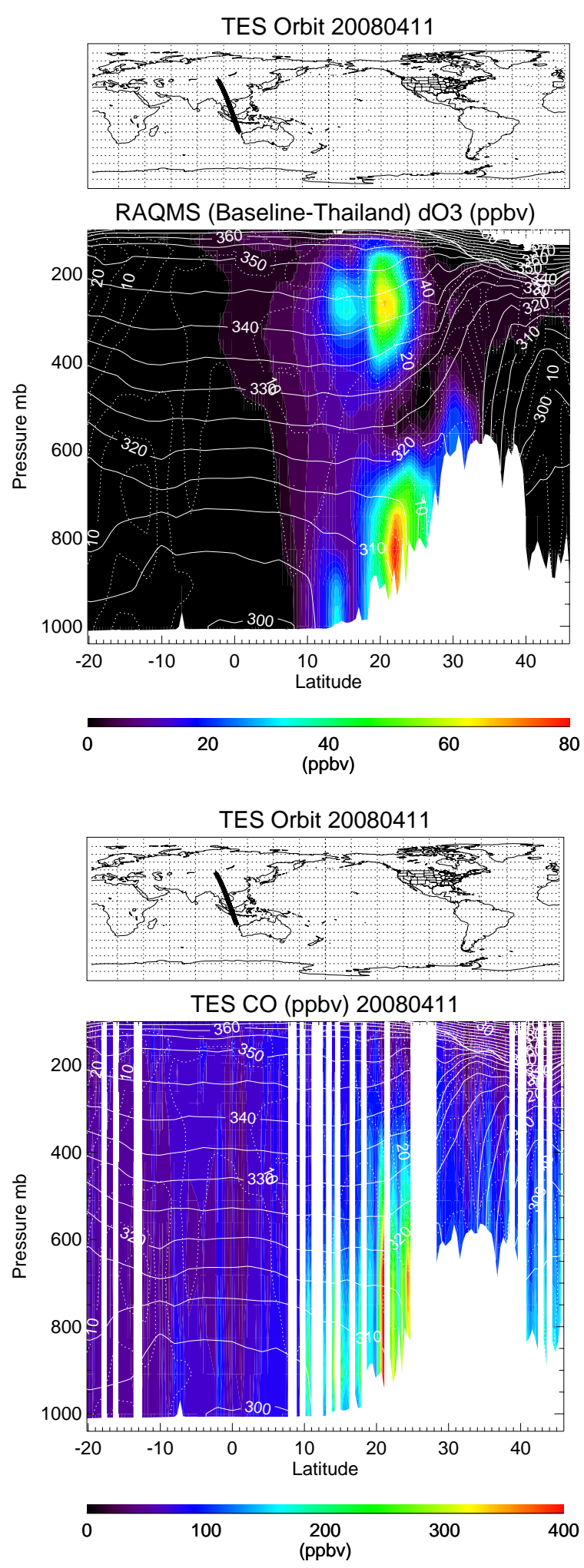

Fig. 12. (Top panel) Estimated ozone due Thailand fires from RAQMS sensitivity runs (bottom panel) estimated CO due to Thailand fires. Right panel shows the orbit track. These figures should be compared to the observed ozone from TES in Fig. 10. 

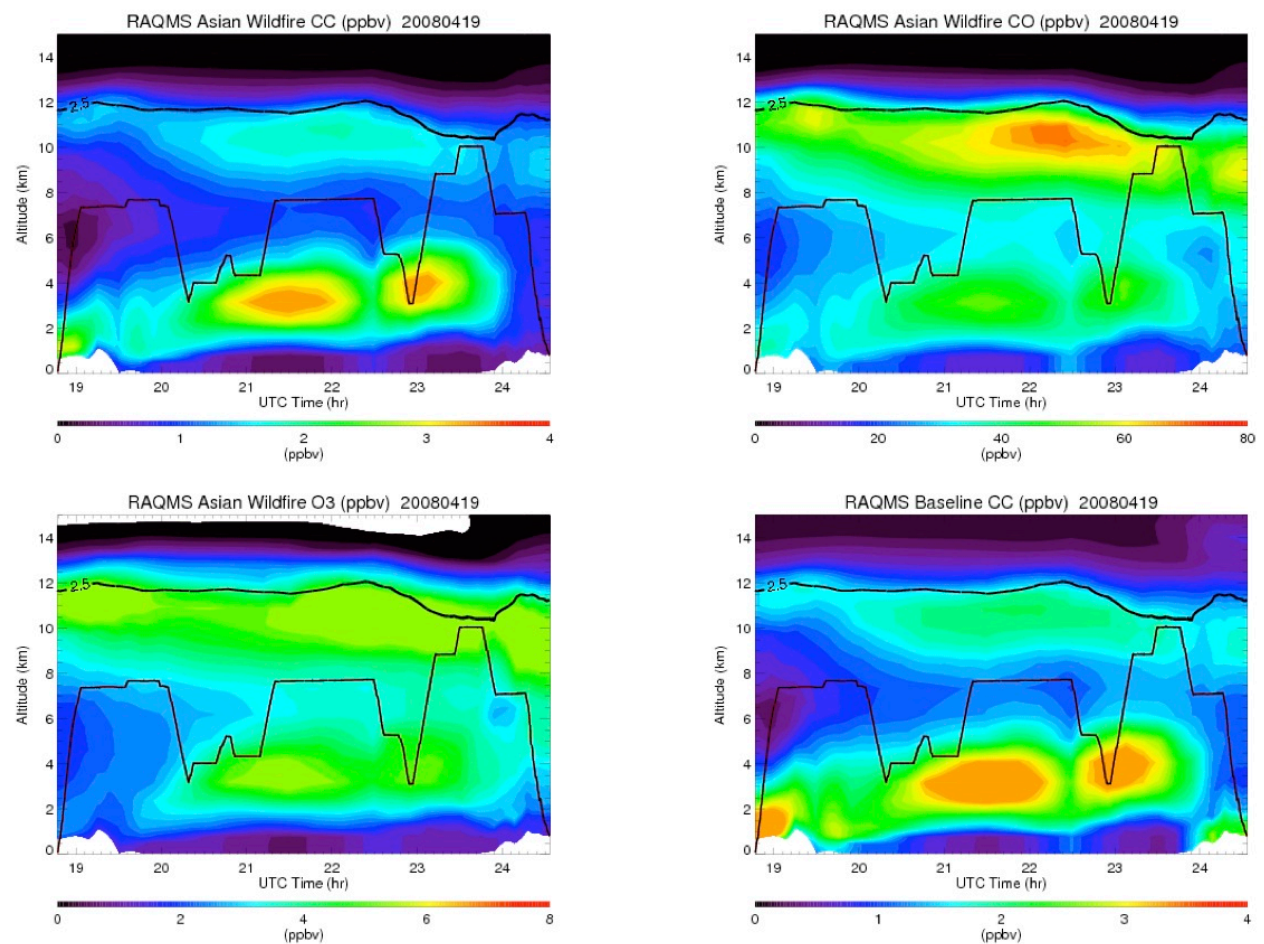

Fig. 13. RAQMS carbonaceous aerosols $(\mathrm{CC})$, carbon monoxide $(\mathrm{CO})$ and ozone $\left(\mathrm{O}_{3}\right)$ enhancements due to Asian wildfires and RAQMS CC baseline concentration profile (from top left to bottom right) along DC8 flight 11.

Figure 13 shows RAQMS Carbonaceous aerosol (CC), $\mathrm{CO}$ and $\mathrm{O}_{3}$ enhancements relative to the baseline simulation due to Asian fire emissions (Kazakhstan, Siberia and Thailand combined) and RAQMS baseline CC along the DC8 flight 11 (from top left to bottom right). The RAQMS baseline CC distribution (bottom right panel) along the DC8 flight curtain agrees spatially with the DIAL measurements (Fig. 4) and shows a major carbon aerosol enhancement in the lower troposphere $(2-6 \mathrm{~km}$ ) (up to $4.6 \mathrm{ppbv}$ ) and lower aerosol amounts in the upper troposphere $(8-12 \mathrm{~km}$ ) (up to $2.4 \mathrm{ppbv}$ ). Comparison between the Asian wildfire and Baseline CC indicates that emissions from Kazakhstan, Baikal, and Thailand wildfires account for more than $90 \%$ of carbonaceous aerosols in the upper and lower/middle troposphere. However, upper tropospheric CC enhancements (2.2 ppbv) are two times less than lower/middle tropospheric enhancements (4.2 ppbv). On the other hand, upper tropospheric $\mathrm{CO}(d \mathrm{CO}=72 \mathrm{ppbv})$ and $\mathrm{O}_{3}\left(d \mathrm{O}_{3}=11 \mathrm{ppbv}\right)$ enhancements are larger than lower tropospheric enhancements $\left(d \mathrm{CO}=50 \mathrm{ppbv}\right.$ and $\left.d \mathrm{O}_{3}=8.5 \mathrm{ppbv}\right)$.

We find that Kazakhstan wildfires account for the majority of lower tropospheric wildfire signatures with peak CC, $\mathrm{CO}$ and $\mathrm{O}_{3}$ enhancements respectively of $3.4 \mathrm{ppbv}, 33 \mathrm{ppbv}$ and $5.5 \mathrm{ppbv}$ (not shown). However, Siberian fires account for a small fraction of lower tropospheric wildfire signatures mostly below $2 \mathrm{~km}$ and at northern $\left(60^{\circ} \mathrm{N}\right)$ part of DC8 flight. As seen before in Sect. 3.1.1, Kazakhstan fire trajecto- ries overpass Siberian fires and entrain emissions from those fires. As a result, impacts on $\mathrm{CO}, \mathrm{CC}$ and $\mathrm{O}_{3}$ by Siberian fires are collocated with Kazakhstan fires $d \mathrm{CC}, d \mathrm{CO}$ and $d \mathrm{O}_{3}$. However, these estimates must be used with caution because the RAQMS model cannot capture the fine vertical extant of the Kazakhstan smoke plume nor the ozone production in the plume that is apparent from the aircraft in situ data; this points to the need for measurements over these sources regions and along the plume in order to better characterize our understanding of the emission, transport, and photochemistry of these fine-scale plumes.

Unlike the Kazakhstan and Siberian fires, the Thailand fires have a significant impact on $\mathrm{CC}, \mathrm{CO}$ and $\mathrm{O}_{3}$ profiles in the upper troposphere. They account for the entire upper tropospheric fire signatures along the DC8 flight path with peak $\mathrm{CC}, \mathrm{CO}$ and $\mathrm{O}_{3}$ enhancements of $2.2 \mathrm{ppbv}, 66 \mathrm{ppbv}$ and $9.5 \mathrm{ppbv}$ respectively. The lower $d \mathrm{CC} / d \mathrm{CO}$ ratios of the Thailand fires relative to the Kazakhstan fires is most likely due to stronger hydrophilic organic carbon and black carbon losses within the Thailand plumes due to convective transport into the upper troposphere.

\section{Conclusions}

Using satellite ozone and CO tropospheric profile estimates from TES, and in situ and lidar data from the ARCTAS campaign, we explored the impact of Siberian Boreal and 
Southeast Asian fires on tropospheric chemistry, long-range transport of associated pollutant over the Pacific, and the chemical and dynamical processes influencing ozone concentrations.

On 19 April 2008, Differential Absorption Lidar (DIAL) onboard of NASA/DC8 aircraft sampled two major biomass burning plumes ashore of western North America. Real time Air Quality Modeling System (RAQMS) ensemble wildfire trajectory analysis showed that those plumes originated from Kazakhstan and Thailand where large wildfires were taking place with monthly mean $\mathrm{CO}$ emissions up to three times higher than usual April means. In-situ measurements onboard the aircraft showed high concentrations of $\mathrm{CO}$, PAN, and $\mathrm{BC}$ consistent with biomass burning along with signatures of anthropogenic emissions $\left(\mathrm{SO}_{2}\right)$ and significant $\mathrm{O}_{3}$ enhancements (up to $100 \mathrm{ppbv}$ ). RAQMS sensitivity studies allowed us to assess the relative impact of Asian fires on $\mathrm{CO}, \mathrm{O}_{3}$ and $\mathrm{CC}$ concentrations along DIAL profiles. It showed that Thailand fires were responsible for almost the entire biomass burning signature in the upper troposphere ( 8 to $12 \mathrm{~km}$ ); whereas Kazakhstan and Siberian fires were responsible for the majority of the fire signature in the lower middle troposphere ( 2 to $6 \mathrm{~km}$ ).

We examined $\mathrm{CO}$ and $\mathrm{O}_{3}$ concentrations within these two distinct plumes using TES and RAQMS data and characterized the evolution of the ozone and CO concentrations, and their correlations, along their respective transport pathways. Over the Kazakhstan fire source region, the model suggests that a significant component of the $\mathrm{O}_{3}$ observed by TES was due to stratospheric enhancement. Upon transport eastward in the middle troposphere over Asia, the plume went over the Siberian fire and was exposed to additional $\mathrm{CO}$ and $\mathrm{O}_{3}$ precursor enhancements as indicated by both the RAQMS model and the aircraft in situ data. Finally, the plume crossed the Pacific over the Bering Sea and reached the flight location on 19 April. Along the flight track, TES and RAQMS observe similar $\mathrm{O}_{3}$ concentrations ranging from 40 to $60 \mathrm{ppbv}$. However, in situ measurements from flight 11 measured $\mathrm{O}_{3}$ concentrations ranging from 80 to $100 \mathrm{ppbv}$ in the plume; this increased ozone enhancement measured by aircraft could be due to localized ozone production within narrow filaments of the wildfire plume that are not observed by TES due to its relatively coarse vertical resolution and not captured by RAQMS due to it's relatively coarse vertical and horizontal resolution and due to transport errors.

The upper tropospheric plume observed by DIAL originated from Thailand in Southeast Asia. TES observations near the source indicate photochemical production of ozone in the plume along with uplift of the plume into the upper troposphere south of the Tibetan plateau, similar to the convective lofting affecting ozone during the summertime Asian monsoon (e.g. Liu et al., 2009; Worden et al., 2009). As indicated by the LIDAR data (Fig. 5), the TES data and the RAQMS model in Figs. 10 and 11, stratospheric air with high ozone and low CO concentrations likely mixed into the edges of the plume (e.g. Jourdain et al., 2009). Then, the plume was transported in the middle/upper troposphere (between 100-400 hPa) over the Pacific. Along the flight track, on 19 April, TES and the adjusted RAQMS model give $\mathrm{O}_{3}$ concentrations ranging from 50 to almost $420 \mathrm{ppbv}$. These estimates of ozone and $\mathrm{CO}$ due to both the fires and stratospheric exchange are limited by the coarse $(\sim 6 \mathrm{~km})$ vertical resolution of TES and the transport and emissions uncertainties in the RAQMS model. However, this study represents one of the first times that observations of ozone were tracked from the source to aircraft using satellite data where they could be interpreted using the suite of measurements of ozone pre-cursors aboard the aircraft. The satellite data complement the aircraft data by observing the effects of stratospheric/tropospheric exchange on ozone concentrations and convective lofting on the smoke plumes prior to being measured by the aircraft.

Considering the seasonal trend of biomass burning pollutant transport from Asia, it is important to characterize these events in order to understand their impact on air quality and climate. Recently, increases in $\mathrm{CO}$ by biomass burning in boreal forests and Southeast Asian fire emissions have been identified as affecting human health (Maynard and Waller, 1999) and perturbing atmospheric chemistry at regional and even global scales (Logan et al., 1981; Roths and Harris, 1996; Novelli et al., 1998; Bowman et al., 2009; Jones et al., 2009). Increases in population in Southeast Asia tend to increase burning of postharvest agricultural waste that is an important type of biomass burning in this region of the world (Crutzen and Andreae, 1990; Nguyen et al., 1994). Increased temperatures from global warming also tend to increase drought and decrease snow cover in Northern Asia leading to increases in fuel quantity and a longer fire season (Euskirchen et al., 2007).

Acknowledgements. HCN measurements were obtained from the Caltech Chemical Ionization Mass Spectrometer and were made available by P. O. Wennberg, J. C. Crounse and A. Kurten. Support for Caltech from NASA (NAG: NNX08AD29G) is gratefully acknowledged.

The views, opinions, and findings contained in this report are those of the author(s) and should not be construed as an official National Oceanic and Atmospheric Administration or US Government position, policy, or decision.

This research was carried out at the Jet Propulsion Laboratory, California Institute of Technology, under a contract with NASA.

Edited by: K. Law 


\section{References}

Abel, S. J., Highwood, E. J., Haywood, J. M., and Stringer, M. A.: The direct radiative effect of biomass burning aerosols over southern Africa, Atmos. Chem. Phys., 5, 1999-2018, doi:10.5194/acp-5-1999-2005, 2005.

Al-Saadi, J. A., Soja, A., Pierce, R. B., Szykman, J., Wiedinmyer, C., Emmons, L., Kondragunta, S., Zhang, X. Y., Kittaka, C., Schaack, T., and Bowman, K.: Intercomparison of near-real-time biomass burning emissions estimates constrained by satellite fire data, J. Appl. Remote Sens., 2, 021504, doi:10.1117/1.2948785, 2008.

Andreae, M. O. and Merlet, P.: Emission of trace gases and aerosols from biomass burning, Global Biogeochem. Cy., 15, 955-966, doi:10.1029/2000GB001382, 2001.

Andreae, M. O.: Soot carbon and excess fine potassium - Longrange transport of combustion-derived aerosols, Science, 220, 1148-1151, 1983.

Beer, R.: TES on the Aura Mission: Scientific objectives, measurements and analysis overview, IEEE T. Geosci. Remote Sens., 44, 1102-1105, doi:10.1109/TGRS.2005.863716, 2006.

Beer, R., Glavich, T. A., and Rider, D. M.: Tropospheric emission spectrometer for the Earth Observing System's Aura satellite, Appl. Opt., 40, 2356-2367, doi:10.1364/AO.40.002356, 2001.

Bertschi, I. T. and Jaffe, D. A.: Long-range transport of ozone, carbon monoxide, and aerosols to the NE Pacific troposphere during the summer of 2003: Observations of smoke plumes from Asian boreal fires, J. Geophys. Res., 110, D05303, doi:10.1029/2004JD005135, 2005.

Bey, I., Jacob, D. J., Yantosca, R. M., Logan, J. A., Field, B. D., Fiore, A. M., Li, Q., Liu, H. Y., Mickley, L. J., and Schultz, M. G.: Global modeling of tropospheric chemistry with assimilated meteorology: Model description and evaluation, J. Geophys. Res., 106, 23073-23096, 2001.

Bian, H., Prather, M., and Takemura, T.: Tropospheric aerosol impacts on trace-gas budgets through photolysis, J. Geophys. Res., 108, 4242, doi:10.1029/2002JD002743, 2003.

Bowman, K. W., Rodgers, C. D., Kulawik, S. S., Worden, J., Sarkissian, E., Osterman, G., Steck, T., Ming Lou, Eldering, A., Shephard, M., Worden, H., Lampel, M., Clough, S., Brown, P., Rinsland, C., Gunson, M., and Beer, R.: Tropospheric emission spectrometer: Retrieval method and error analysis, IEEE T. Geosci. Remote Sens., 44, 1297-1307, doi:10.1109/TGRS.2006.871234, 2006.

Bowman, K. W., Jones, D. B. A., Logan, J. A., Worden, H., Boersma, F., Chang, R., Kulawik, S., Osterman, G., Hamer, P., and Worden, J.: The zonal structure of tropical $\mathrm{O}_{3}$ and $\mathrm{CO}$ as observed by the Tropospheric Emission Spectrometer in November 2004 - Part 2: Impact of surface emissions on $\mathrm{O}_{3}$ and its precursors, Atmos. Chem. Phys., 9, 3563-3582, doi:10.5194/acp-93563-2009, 2009.

Browell, E. V., Fenn, M. A., Butler, C. F., Grant, W. B., Ismail, S., Ferrare, R. A., Kooi, S. A., Brackett, V. G., Clayton, M. B., Avery, M. A., Barrick, J. D. W., Fuelberg, H. E., Maloney, J. C., Newell, R. E., Zhu, Y., Mahoney, M. J., Anderson, B. E., Blake, D. R., Brune, W. H., Heikes, B. G., Sachse, G. W., Singh, H. B., and Talbot, R. W.: Large-scale air mass characteristics observed over the remote tropical Pacific Ocean during MarchApril 1999: Results from PEM Tropics B Field Experiment, J. Geophys. Res., 106, 32481-32501, 2001.
Cahoon Jr. D. R., Stocks, B. J., Levine, J. S., Cofer III, W. R., and Pierson, J. M.: Satellite analysis of the severe 1987 forest fires in northern China and southeastern Siberia, J. Geophys. Res., 99 18627-18638, 1994.

Chin, M., Ginoux, P., Kinne, S., Torres, O., Holben, B. N., Duncan, B. N., Martin, R. V., Logan, J. A., Higurashi, A., and Nakajima, T.: Tropospheric aerosol optical thickness from the GOCART model and comparisons with satellite and sunphotometer measurements, J. Atmos. Sci., 59, 461-483, doi:10.1175/15200469(2002)059<0461:TAOTFT > 2.0.CO;2, 2002.

Chin, M., Ginoux, P., Lucchesi, R., Huebert, B., Weber, R., Anderson, T., Masonis, S., Blomquist, B., Bandy, A., and Thornton, D.: A global aerosol model forecast for the ACE-Asia field experiment, J. Geophys. Res., 108, 8654, doi:10.1029/2003JD003642, 2003.

Christopher, S. A., Chou, J., Welch, R. M., Kliche, D. V., and Connors, V. S.: Satellite investigations of fire, smoke, and carbon monoxide during April 1994 MAPS mission: Case studies over tropical Asia, J. Geophys. Res., 103, 19327-19336, 1998.

Cofer III, W. R., Levine, J. S., Winstead, E. L., and Stocks, B. J.: Trace gas and particulate emissions from biomass burning in temperate ecosystems, Global Biomass Burning: Atmospheric, Climatic, and Biospheric Implications, edited by: Levine, J. S., MIT Press, Cambridge, Mass., 203-208, 1991.

Conard, S. G., Sukhinin, A. I., Stocks, B. J., Cahoon, D. R., Davidenko, E. P., and Ivanova, G. A.: Determining effects of area burned and fire severity on carbon cycling and emissions in Siberia, Climate Change, 55, 197-211, 2002.

Crutzen, P. J. and Andreae, M. O.: Biomass burning in the tropics: Impact on atmospheric chemistry and biogeochemical cycles, Science, 250, 1669-1678, doi:10.1126/science.250.4988.1669, 1990.

Davies, D., Kumar, S., and Descloitres, J.: Global fire monitoring: Use of MODIS near-real-time satellite data, GIM International, 18, 41-43, 2004.

Dlugokencky, E. J., Walter, B. P., Masarie, K. A., Lang, P. M., and Kasischke, E. S.: Measurements of an anomalous global methane increase during 1998, Geophys. Res. Lett., 28, 499-502, 2001.

Eck, T. F., Holben, B. N., Ward, D. E., Mukelabai, M. M., Dubovik, O., Smirnov, A., Schafer, J. S., Hsu, N. C., Piketh, S. J., Queface, A., Le Roux, J., Swap, R. J., and Slutsker, I.: Variability of biomass burning aerosol optical characteristics in southern Africa during the SAFARI 2000 dry season campaign and a comparison of single scattering albedo estimates from radiometric measurements, J. Geophys. Res., 108, 8477, doi:10.1029/2002JD002321, 2003.

Eckhardt, S., Stohl, A., Beirle, S., Spichtinger, N., James, P., Forster, C., Junker, C., Wagner, T., Platt, U., and Jennings, S. G.: The North Atlantic Oscillation controls air pollution transport to the Arctic, Atmos. Chem. Phys., 3, 1769-1778, doi:10.5194/acp3-1769-2003, 2003.

Edwards, D. P., Emmons, L. K., Hauglustaine, D. A., Chu, D. A., Gille, J. C., Kaufman, Y. J., Petron, G., Yurganov, L. N., Giglio, L., Deeter, M. N., Yudin, V., Ziskin, D. C., Warner, J., Lamarque, J. F., Francis, G. L., Ho, S. P., Mao, D., Chen, J., Grechko E. I., and Drummond, J. R.: Observations of carbon monoxide and aerosols from the Terra satellite: Northern Hemisphere variability, J. Geophys. Res., 109, D24202, doi:10.1029/2004JD004727, 2004. 
Euskirchen, E. S., Mcguire, A. D., and Chapin, F. S.: Energy feedbacks of northern high-latitude ecosystems to the climate system due to reduced snow cover during 20th century warming, Glob. Chan. Biol., 13, 2425-2438, 2007.

Fisher, J. A., Jacob, D. J., Purdy, M. T., Kopacz, M., Le Sager, P., Carouge, C., Holmes, C. D., Yantosca, R. M., Batchelor, R. L., Strong, K., Diskin, G. S., Fuelberg, H. E., Holloway, J. S., Hyer, E. J., McMillan, W. W., Warner, J., Streets, D. G., Zhang, Q., Wang, Y., and Wu, S.: Source attribution and interannual variability of Arctic pollution in spring constrained by aircraft (ARCTAS, ARCPAC) and satellite (AIRS) observations of carbon monoxide, Atmos. Chem. Phys., 10, 977-996, doi:10.5194/acp-10-977-2010, 2010.

Fishman, J., Watson, C. E., Larsen, J. C., and Logan, J. A.: Distribution of tropospheric ozone determined from satellite data, J. Geosphy. Res., 95, 3599-3617, 1990.

Forster, C., Wandinger, U., Wotawa, G., James, P., Mattis, I., Althausen, D., Simmonds, P., O'Doherty, S., Jennings, S. G., Kleefeld, C., Schneider, J., Trickl, T., Kreipl, S., Jager, H., and Stohl, A.: Transport of boreal forest fire emissions from Canada to Europe, J. Geophys. Res., 106, 22887-22906, doi:10.1029/2001JD900115, 2001.

Fromm, M., Alfred, J., Hoppel, K., Hornstein, J., Bevilacqua, R., Shettle, E., Servranckx, R., Li, Z. Q., and Stocks, B.: Observations of boreal forest fire smoke in the stratosphere by POAM III, SAGE II, and lidar in 1998, Geophys. Res. Lett., 27, 1407-1410, 2000.

Goloub, P. and Arino, O.: Verification of the consistency of Polder Aerosol Index over land with ATSR-2/ERS-2 fire product, Geophys. Res. Lett., 27, 899-902, 2000.

Haines, D. A.: A lower atmosphere severity index for wildland fires, Natl. Weather Dig., 13, 23-27, 1988.

Hao, W. M. and Ward, D. E.: Methane production from global biomass burning, J. Geophys. Res., 98, 20657-20661, 1993.

Haywood, J. and Boucher, O.: Estimates of the direct and indirect radiative forcing due to tropospheric aerosols: A review, Rev. Geophys., 38, 513-543, 2000.

Heald, C. L., Daniel, J. J., Arlene, M. F., Louisa, K. E., John, C. G., Merritt, N. D., Juying, W., David, P. E., James, H. C., Amy, J. H., Glen, W. S., Edward, V. B., Melody, A. A., Stephanie, A. V., David, J. W., Donald, R. B., Hanwant, B. S., Scott, T. S., Robert, W. T., and Fuelberg, H. E.: Asian outflow and transPacific transport of carbon monoxide and ozone pollution: An integrated satellite, aircraft, and model perspective, J. Geophys. Res., 108, 4804, doi:10.1029/2003JD003507, 2003.

Ho, S., Edwards, D. P., Gille, J. C., Luo, M., Osterman, G. B., Kulawik, S. S., and Worden, H.: A global comparison of carbon monoxide profiles and column amounts from Tropospheric Emission Spectrometer (TES) and Measurements of Pollution in the Troposphere (MOPITT), J. Geophys. Res., 114, D21307, doi:10.1029/2009JD012242, 2009.

Jacob, D. J., Crawford, J. H., Kleb, M. M., Connors, V. S., Bendura, R. J., Raper, J. L., Sachse, G. W., Gille, J. C., Emmons, L., and Heald, C. L.: Transport and Chemical Evolution over the Pacific (TRACE-P) aircraft mission: Design, execution, and first results, J. Geophys. Res., 108, 9000, doi:10.1029/2002JD003276, 2003.

Jacob, D. J., Crawford, J. H., Maring, H., Clarke, A. D., Dibb, J. E., Emmons, L. K., Ferrare, R. A., Hostetler, C. A., Russell, P. B., Singh, H. B., Thompson, A. M., Shaw, G. E., McCauley, E., Ped- erson, J. R., and Fisher, J. A.: The Arctic Research of the Composition of the Troposphere from Aircraft and Satellites (ARCTAS) mission: design, execution, and first results, Atmos. Chem. Phys., 10, 5191-5212, doi:10.5194/acp-10-5191-2010, 2010.

Jaffe, D., Mahula, A., Kelley, J., Atkins, J., Novelli, P. C., and Merrill, J.: Impact of Asian emissions on the remote North Pacific atmosphere: Interpretation of CO data from Shemya, Guam, Midway and Mauna Loa, J. Geophys. Res., 102, 28627-28635, 1997.

Jaffe, D., Bertschi, I., Jaegle, L., Novelli, P., Reid, J. S., Tanimoto, H., Vingarzan, R., and Westphal, D. L.: Long-range transport of Siberian biomass burning emissions and impact on surface ozone in western North America, Geophys. Res. Lett., 31, L16106, doi:10.1029/2004GL020093, 2004.

Jones, D. B. A., Bowman, K. W., Logan, J. A., Heald, C. L., Liu, J., Luo, M., Worden, J., and Drummond, J.: The zonal structure of tropical $\mathrm{O}_{3}$ and $\mathrm{CO}$ as observed by the Tropospheric Emission Spectrometer in November 2004 - Part 1: Inverse modeling of CO emissions, Atmos. Chem. Phys., 9, 3547-3562, doi:10.5194/acp-9-3547-2009, 2009.

Jourdain, L., Kulawik, S. S., Worden, H. M., Pickering, K. E., Worden, J., and Thompson, A. M.: Lightning $\mathrm{NO}_{\mathrm{x}}$ emissions over the USA constrained by TES ozone observations and the GEOS-Chem model, Atmos. Chem. Phys., 10, 107-119, doi:10.5194/acp-10-107-2010, 2010.

Kajii, Y., Kato, S., Streets, D. G., Tsai, N. Y., Shvidenko, A., Nilsson, S., McCallum, I., Minko, N. P., Abushenko, N., Altyntsev, D., and Khodzer, T. V.: Boreal forest fires in Siberia in 1998: Estimation of area burned and emissions of pollutants by advanced very high resolution radiometer satellite data, J. Geophys. Res., 107, 4745, doi:10.1029/2001JD001078, 2002.

Kasischke, E. S. and Bruhwiler, L. P.: Emissions of carbon dioxide, carbon monoxide, and methane from boreal forest fires in 1998, J. Geosphy. Res., 108, 8146, doi:10.1029/2001JD000461, 2003.

Kasischke, E. S., Hyer, E. J., Novelli, P. C., Bruhwiler, L. P., French, N. H. F., Sukhinin, A. I., Hewson, J. H., and Stocks, B. J.: Influence of boreal fire emissions on Northern Hemisphere atmospheric carbon and carbon monoxide, Global Biogeochem. Cy., 19, GB1012, doi:10.1029/2004GB002300, 2005.

Kato, S., Pochanart, P., Hirokawa, J., Kajii, Y., Akimoto, H., Ozaki, Y., Obi, K., Katsuno, T., Streets, D. G., and Minko, N. P.: The influence of Siberian forest fires on carbon monoxide concentrations at Happo, Japan, Atmos. Environ., 36, 385-390, 2002.

Kittaka, C., Pierce, R. B,, Crawford, J. H., Hitchman, M. H., Johnson, D. R., Tripoli, G. J., Chin, M., Bandy, A. R., Weber, R. J., Talbot, R. W., and Anderson, B. E.: A three-dimensional regional modeling study of the impact of clouds on sulfate distributions during TRACE-P, J. Geophys. Res., 109, D15S11, doi:10.1029/2003JD004353, 2004.

Klonecki, A., Hess, P., Emmons, L., Smith, L., Orlando, J., and Blake, D.: Seasonal changes in the transport of pollutants into the Arctic troposphere-model study, J. Geophys. Res., 108, 8367, doi:10.1029/2002JD002199, 2003.

Koch, D. and Hansen, J.: Distant origins of Arctic black carbon: A Goddard Institute for Space Studies ModelE experiment, J. Geophys. Res., 110, D04204, doi:10.1029/2004JD005296, 2005.

Lapina, K., Honrath, R. E., Owen, R. C., Val Martin, M., and Pfister, G.: Evidence of significant large-scale impacts of boreal fires on ozone levels in the midlatitude Northern Hemisphere free troposphere, Geophys. Res. Lett., 33, L10815, 
doi:10.1029/2006GL025878, 2006

Liang, Q., Jaegle, L., Jaffe, D. A., Weiss-Penzias, P., Heckman, A., and Snow, J. A.: Long-range transport of Asian pollution to the northeast Pacific: Seasonal variations and transport pathways of carbon monoxide, J. Geophys. Res., 109, D23S07, doi:10.1029/2003JD004402, 2004.

Liu, H., Jacob, D. J., Bey, I., Yantosca, R. M., Duncan, B. N., and Sachse, G. W.: Transport pathways for Asian pollution outflow over the Pacific: Interannual and seasonal variations, J. Geophys. Res., 108, 8786, doi:10.1029/2002JD003102, 2003.

Liu, J. J., Jones, D. B. A., Worden, J. R., Noone, D., Parrington, M., and Kar, J.: Analysis of the summertime buildup of tropospheric ozone abundances over the Middle East and North Africa as observed by the Tropospheric Emission Spectrometer instrument, J. Geophys. Res., 114, D05304, doi:10.1029/2008JD010993, 2009.

Logan, J. A., Prather, M. J., Wofsy, S. C., and McElroy, M. B.: Tropospheric Chemistry: A Global Perspective, J. Geophys. Res., 86, 7210-7254, 1981.

Lopez, J. P., Luo, M., Christensen, L. E., Loewenstein, M., Jost, H., Webster, C. R., and Osterman, G.: TES carbon monoxide validation during two AVE campaigns using the Argus and ALIAS instruments on NASA's WB-57F, J. Geophys. Res., 113, D16S47, doi:10.1029/2007JD008811, 2008.

Luo, M., Rinsland, C., Fisher, B., Sachse, G., Diskin, G., Logan, J., Worden, H., Kulawik, S., Osterman, G., Eldering, A., Herman, R., and Shephard, M.: TES carbon monoxide validation with DACOM aircraft measurements during INTEX-B 2006, J. Geophys. Res., 112, D24S48, doi:10.1029/2007JD008803, 2007.

Massie, S. T., Torres, O., and Smith, S. J.: Total Ozone Mapping Spectrometer (TOMS) observations of increases in Asian aerosol in winter from 1979 to 2000, J. Geophys. Res.-Atmos., 109, D18211, doi:10.1029/2004JD004620, 2004.

Mauzerall, D. L., Jacob, D. J., Fan, S. M., Bradshaw, J. D., Gregory, G. L., Sachse, G. W., and Blake, D. R.: Origin of tropospheric ozone at remote high northern latitudes in summer, J. Geophys. Res., 101, 4175-4188, doi:10.1029/95JD03224, 1996.

Mauzerall, D. L., Logan, J. A., Jacob, D. J., Anderson, B. E., Blake, D. R., Bradshaw, J. D., Heikes, B., Sachse, G. W., Singh, H., and Talbot, B.: Photochemistry in biomass burning plumes and implications for tropospheric ozone over the tropical South Atlantic, J. Geophys. Res.-Atmos., 103, 8401-8423, 1998.

Maynard, R. L. and Waller, R.: Carbon monoxide, Air Pollution and health, edited by: Holgate, S. T., Samet, J. M., Koren, H. S., and Maynard, R. L., Academic, San Diego, Calif., 749-796, 1999.

Morris, G. A., Hersey, S., Thompson, A. M., Pawson, S., Nielsen, J. E., Colarco, P. R., McMillan, W. W., Stohl, A., Turquety, S., Warner, J., Johnson, B. J., Kucsera, T. L., Larko, D. E., Oltmans, S. J., and Witte, J. C.: Alaskan and Canadian forest fires exacerbate ozone pollution over Houston, Texas, on 19 and 20 July 2004, J. Geophys. Res., 111, D24S03, doi:10.1029/2006JD007090, 2006.

Myhre, G., Berntsen, T. K., Haywood, J. M., Sundet, J. K., Holben, B. N., Johnsrud, M., and Stordal, F.: Modeling the solar radiative impact of aerosols from biomass burning during the Southern African Regional Science Initiative (SAFARI-2000) experiment, J. Geophys. Res., 108, 8501, doi:10.1029/2002JD002313, 2003.

Nassar, R., Logan, J. A., Worden, H., Megretskaia, I. A., Bowman, K. W., Osterman, G., Thompson, A. M., Tarasick, D. W., Austin,
S., Claude, H., Dubey, M. K., Hocking, W. K., Johnson, B. J., Joseph, E., Merrill, J., Morris, G. A., Newchurch, M., Oltmans, S. J., Posny, F., Schmidlin, F. J., Vomel, H., Whiteman, D. N., and Witte, J. C.: Validation of Tropospheric Emission Spectrometer (TES) nadir ozone profiles using ozonesonde measurements, J. Geophys. Res., 113, D15S17, doi:10.1029/2007JD008819, 2008.

Nedelec, P., Thouret, V., Brioude, J., Sauvage, B., Cammas, J.-P., and Stohl, A.: Extreme CO concentrations in the upper troposphere over northeast Asia in June 2003 from the in situ MOZAIC aircraft data, Geophys. Res. Lett., 32, L14807, doi:10.1029/2005GL023141, 2005.

Nguyen, B. C., Mihalopoulos, N., and Putaud, J.-P.: Rice straw burning in Southeast Asia as a source of CO and COS to the atmosphere, J. Geophys. Res., 99, 16435-16439, 1994.

Novelli, P. C., Masarie, K. A., and Lang, P. M.: Distributions and recent changes of carbon monoxide in the lower troposphere, J. Geophys. Res., 103, 19015-19033, 1998.

Novelli, P. C., Masarie, K. A., Lang, P. M., Hall, B. D., Myers, R. C., and Elkins, J. W.: Reanalysis of tropospheric CO trends: Effects of the 1997-1998 wildfires, J. Geophys. Res., 108, 4464, doi:10.1029/2002JD003031, 2003.

Osterman, G.: Tropospheric emission spectrometer (TES) validation report, JPL D33192, version 3.0, Jet Propul. Lab., Pasadena, Calif., available at: http://tes.jpl.nasa.gov/documents/, 2007.

Pfister, G., Hess, P. G., Emmons, L. K., Lamarque, J.-F., Wiedinmyer, C., Edwards, D. P., Petron, G., Gille, J. C., and Sachse, G. W.: Quantifying CO emissions from the 2004 Alaskan wildfires using MOPITT CO data, Geophys. Res. Lett., 32, L11809, doi:10.1029/2005GL022995, 2005.

Pierce, R. B., Al-Saadi, J. A., Schaack, T., Lenzen, A., Zapotocny, T., Johnson, D., Kittaka, C., Buker, M., Hitchman, M. H., Tripoli, G., Fairlie, T. D., Olson, J. R., Natarajan, M., Crawford, J., Fishman, J., Avery, M., Browell, E. V., Creilson, J., Kondo, Y., and Sandholm, S. T.: Regional Air Quality Modeling System (RAQMS) predictions of the tropospheric ozone budget over east Asia, J. Geophys. Res., 108, 8825, doi:10.1029/2002JD003176, 2003.

Pierce, R. B., Schaack, T., Al-Saadi, J. A., Fairlie, T. D., Kittaka, C., Lingenfelser, G., Natarajan, M., Olson, J., Soja, A., Zapotocny, T., Lenzen, A., Stobie, J., Johnson, D., Avery, M. A., Sachse, G. W., Thompson, A., Cohen, R., Dibb, J. E., Crawford, J., Rault, D., Martin, R., Szykman, J., and Fishman, J.: Chemical data assimilation estimates of continental U.S. ozone and nitrogen budgets during the Intercontinental Chemical Transport Experiment-North America, J. Geophys. Res., 112, D12S21, doi:10.1029/2006JD007722, 2007.

Pierce, R. B., Al-Saadi, J., Kittaka, C., Schaack, T., Lenzen, A., Bowman, K., Szykman, J., Soja, A., Ryerson, T., Thompson, A. M., Bhartia, P., and Morris, G. A.: Impacts of background ozone production on Houston and Dallas, Texas, air quality during the Second Texas Air Quality Study field mission, J. Geophys. Res.Atmos., 114, D00F09, doi:10.1029/2008JD011337, 2009.

Pochanart, P., Akimoto, H., Kajii, Y., and Sukasem, P.: Carbon monoxide, regional-scale transport, and biomass burning in tropical continental Southeast Asia: Observations in rural Thailand, J. Geophys. Res., 108, 4552, doi:10.1029/2002JD003360, 2003.

Quinn, P. K., Shaw, G., Andrews, E., Dutton, E. G., RuohoAirola, T., and Gong, S. L.: Arctic haze: current trends and 
knowledge gaps, Tellus B, 59, 99-114, doi:10.1111/j.16000889.2006.00238.x, 2007.

Real, E., Law, K. S., Weinzierl, B., Fiebig, M., Petzold, A., Wild, O., Methven, J., Arnold, S., Stohl, A., Huntrieser, H., Roiger, A., Schlager, H., Stewart, D., Avery, M., Sachse, G., Browell, E., Ferrare, R., and Blake, D.: Processes influencing ozone levels in Alaskan forest fire plumes during long-range transport over the North Atlantic, J. Geophys. Res., 112, D10S41, doi:10.1029/2006JD007576, 2007

Reichle, H. G., Connors, V. S., Holland, J. A., Hypes, W. D., Wallio, H. A., Casas, J. C., Gormsen, B. B., and Saylor, M. S.: Middle and upper tropospheric carbon-monoxide mixing ratios as measured by satellite-borne remote sensor during November 1981, J. Geophys. Res., 91, 865-887, 1986.

Reid, J. S., Koppmann, R., Eck, T. F., and Eleuterio, D. P.: A review of biomass burning emissions part II: intensive physical properties of biomass burning particles, Atmos. Chem. Phys., 5, 799825, doi:10.5194/acp-5-799-2005, 2005.

Reid, J. S., Eck, T. F., Christopher, S. A., Koppmann, R., Dubovik, O., Eleuterio, D. P., Holben, B. N., Reid, E. A., and Zhang, J.: A review of biomass burning emissions part III: intensive optical properties of biomass burning particles, Atmos. Chem. Phys., 5, 827-849, doi:10.5194/acp-5-827-2005, 2005.

Remer, L. A., Kaufman, Y. J., Tanre', D., Mattoo, S., Chu, D. A., Martins, J. V., Li, R.-R., Ichoku, C., Levy, R. C., Kleidman, R. G., Eck, T. F., and Vermote, E.: The MODIS aerosol algorithm, products and validation, J. Atmos. Sci., 62, 947-973, doi:10.1175/JAS3385.1, 2005.

Richards, N. A. D., Li, Q. B., Osterman, G. B., Browell, E. V., Avery, M., and Bowman, K. W.: Validation of Tropospheric Emission Spectrometer (TES) measurements of the total, stratospheric, and tropospheric column abundance of ozone, J. Geophys. Res., 113, D15S16, doi:10.1029/2007JD008801, 2008.

Roths, J. and Harris, G. W.: The tropospheric distribution of carbon monoxide as observed during the Tropoz II Experiment, J. Atmos. Chem., 24, 157-188, 1996.

Seiler, W. and Crutzen, P. J.: Estimates of gross and net fluxes of carbon between the biosphere and the atmosphere from biomass burning, Climate Change, 2, 207-247, 1980.

Shaw, G. E.: The arctic haze phenomenon, B. Am. Meteorol. Soc., 76, 2403-2413, 1995.

Shindell, D. T., Chin, M., Dentener, F., Doherty, R. M., Faluvegi, G., Fiore, A. M., Hess, P., Koch, D. M., MacKenzie, I. A., Sanderson, M. G., Schultz, M. G., Schulz, M., Stevenson, D. S., Teich, H., Textor, C., Wild, O., Bergmann, D. J., Bey, I., Bian, H., Cuvelier, C., Duncan, B. N., Folberth, G., Horowitz, L. W., Jonson, J., Kaminski, J. W., Marmer, E., Park, R., Pringle, K. J., Schroeder, S., Szopa, S., Takemura, T., Zeng, G., Keating, T. J., and Zuber, A.: A multi-model assessment of pollution transport to the Arctic, Atmos. Chem. Phys., 8, 5353-5372, doi:10.5194/acp-8-5353-2008, 2008.

Simmonds, P. G., Manning, A. J., Derwent, R. G., Ciais, P., Ramonet, M., Kazan, V., and Ryall, D.: A burning question: Can recent growth rate anomalies in the greenhouse gases be attributed to large-scale biomass burning events?, Atmos. Environ., 39, 2513-2517, doi:10.1016/j.atmosenv.2005.02.018, 2005.

Singh, H. B. and Hanst, P. L.: Peroxyacetyl Nitrate (PAN) in the unpolluted atmosphere - an important reservoir for NitrogenOxides, Geophys. Res. Lett., 8, 941-944, 1981.
Soja, A. J., Cofer, W. R., Shugart, H. H., Sukhinin, A. I., Stackhouse, P. W., McRae, D. J., and Conard, S. G.: Estimating fire emissions and disparities in boreal Siberia (1998-2002), J. Geophys. Res.-Atmos., 109, D14S06, doi:10.1029/2004JD004570, 2004.

Soja, A. J., Tchebakova, N. M., French, N. H. F., Flannigan, M. D., Shugart, H. H., Stocks, B. J., Sukhinin, A. I., Parfenova, E. I., Chapin, F. S., and Stackhouse, P. W.: Climate-induced boreal forest change: Predictions versus current observations, Glob. Planet. Change, 56, 274-296, 2007.

Staudt, A. C., Jacob, D. J., Logan, J. A., Bachiochi, D., Krishnamurti, T. N., and Sachse, G. W.: Continental sources, transoceanic transport, and interhemispheric exchange of carbon monoxide over the Pacific, J. Geophys. Res., 106, 32571-32590, 2001.

Stohl, A.: Characteristics of atmospheric transport into the Arctic troposphere, J. Geophys. Res., 111, D11306, doi:10.1029/2005JD006888, 2006.

Tanimoto, H., Kajii, Y., Hirokawa, J., Akimoto, H., and Minko, N. P.: The atmospheric impact of boreal forest fires in far eastern Siberia on the seasonal variation of carbon monoxide: Observations at Rishiri, a northern remote island in Japan, Geophys. Res. Lett., 27, 4073-4076, 2000.

Thompson, A. M., Hogan, K. B., and Hoffman, J. S.: Methane reductions - Implications for global warming and atmospheric chemical-change, Atmos. Environ., 26, 2665-2668, 1992.

Turquety, S., Clerbaux, C., Law, K., Coheur, P.-F., Cozic, A., Szopa, S., Hauglustaine, D. A., Hadji-Lazaro, J., Gloudemans, A. M. S., Schrijver, H., Boone, C. D., Bernath, P. F., and Edwards, D. P.: $\mathrm{CO}$ emission and export from Asia: an analysis combining complementary satellite measurements (MOPITT, SCIAMACHY and ACE-FTS) with global modeling, Atmos. Chem. Phys., 8, 5187-5204, doi:10.5194/acp-8-5187-2008, 2008.

Val Martin, M., Honrath, R., Owen, R. C., Pfister, G., Fialho, P., and Barata, F.: Significant enhancements of nitrogen oxides, ozone and aerosol black carbon in the North Atlantic lower free troposphere resulting from North American boreal wildfires, J. Geophys. Res., 111, D23S60, doi:10.1029/2006JD007530, 2006.

van der Werf, G. R., Randerson, J. T., Giglio, L., Collatz, G. J., Kasibhatla, P. S., and Arellano Jr., A. F.: Interannual variability in global biomass burning emissions from 1997 to 2004, Atmos. Chem. Phys., 6, 3423-3441, doi:10.5194/acp-6-3423-2006, 2006.

Verma, S., Worden, J. R., Pierce, R. B., Jones D. B. A., Al-Saadi, J., Boersma, F., Bowman, K., Eldering, A., Fisher, B., Jourdain, L., Kulawik, S., and Worden, H.: Ozone production in boreal fire smoke plumes using observations from the Tropospheric Emission Spectrometer and the Ozone Monitoring Instrument, J. Geophys. Res., 114, D02303, doi:10.1029/2008JD010108, 2009.

Warneke, C., Bahreini, R., Brioude, J., Brock, C. A., de Gouw, J. A., Fahey, D. W., Froyd, K. D., Holloway, J. S., Middlebrook, A., Miller, L., Montzka, S., Murphy, D. M., Peischl, J., Ryerson, T. B., Schwarz, J. P., Spackman, J. R., and Veres, P.: Biomass burning in Siberia and Kazakhstan as an important source for haze over the Alaskan Arctic in April 2008, Geophys. Res. Lett., 36, L02813, doi:10.1029/2008g1036194, 2009.

Worden, J., Kulawik, S. S., Shephard, M. W., Clough, S. A., Worden, H., Bowman, K., and Goldman, A.: Predicted errors of tropospheric emission spectrometer nadir retrievals from 
spectral window selection, J. Geophys. Res., 109, D09308, doi:10.1029/2004JD004522, 2004.

Worden, H. M., Logan, J. A., Worden, J. R., Beer, R., Bowman, K., Clough, S. A., Eldering, A., Fisher, B. M., Gunson, M. R., Herman, R. L., Kulawik, S. S., Lampel, M. C., Luo, M., Megretskaia, I. A., Osterman, G. B., and Shephard, M. W.: Comparisons of Tropospheric Emission Spectrometer (TES) ozone profiles to ozonesondes: Methods and initial results, J. Geophys. Res., 112, D03309, doi:10.1029/2006JD007258, 2007.

Worden, John , Dylan B. A. Jones, Jane Liu, Mark Parrington, Kevin Bowman, Ivanka Stajner, Reinhard Beer, Jonathan Jiang, Valérie Thouret, Susan Kulawik, Jui-Lin F. Li, Sunita Verma, Helen Worden, Observed vertical distribution of tropospheric ozone during the Asian summertime monsoon, J. Geophys. Res., 114, D13304, doi:10.1029/2008JD010560, 2009.

Wotawa, G. and Trainer, M.: The influence of Canadian forest fires on pollutant concentrations in the United States, Science, 288, 324-328, doi:10.1126/science.288.5464.324, 2000.

Yashiro, H., Sugawara, S., Sudo, K., Aoki, S., and Nakazawa, T.: Temporal and spatial variations of carbon monoxide over the western part of the Pacific Ocean, J. Geophys. Res., 114, D08305, doi:10.1029/2008jd010876, 2009.
Yurganov, L. N., Jaffe, D. A., Pullman, E., and Novelli, P. C.: Total column and surface densities of atmospheric carbon monoxide in Alaska, 1995, J. Geophys. Res., 103, 19337-19345, 1998.

Zhang, L., Jacob, D. J., Bowman, K. W., Logan, J. A., Turquety, S., Hudman, R. C., Li, Q., Beer, R., Worden, H. M., Worden, J. R., Rinsland, C. P., Kulawik, S. S., Lampel, M. C., Shephard, M. W., Fisher, B. M., Eldering, A., and Avery, M. A.: Continental outflow of ozone pollution as determined by O3-CO correlations from the TES satellite instrument, Geophys. Res. Lett., 33, L18804, doi:10.1029/2006GL026399, 2006.

Zhao, T. X. P., Stowe, L. L., Smirnov, A., Crosby, D., Sapper, J., and McClain, C. R.: Development of a global validation package for satellite oceanic aerosol optical thickness retrieval based on AERONET observations and its application to NOAA/NESDIS operational aerosol retrievals, J. Atmos. Sci., 59, 294-312, 2002. 